\title{
Multinationals, innovation, and institutional context: IPR protection and distance effects
}

\author{
Randolph Luca Bruno ${ }^{1,2,3}$, \\ Riccardo Crescenzi ${ }^{4}$, \\ Saul Estrin ${ }^{5}$ and \\ Sergio Petralia 4
}

${ }^{1}$ SSEES, University College London, London, UK; ${ }^{2}$ IZA Word of Labor, Bonn, Germany; ${ }^{3}$ Fondazione Rodolfo DeBenedetti, Milan, Italy; ${ }^{4}$ Department of Geography and Environment, London School of Economics, London, UK; ${ }^{5}$ Department of Management, London School of Economics, London, UK

Correspondence:

S Estrin, Department of Management, London School of Economics, London, UK e-mail: s.estrin@Ise.ac.uk

\begin{abstract}
We characterize the knowledge production process whereby the inventive capabilities of the firm generate innovation output in highly inventive multinational enterprises (MNEs). We explore the sensitivity of this relationship to the strength of intellectual property rights (IPR) protection across the MNEs R\&D subsidiaries. We argue that MNE innovative performance will be enhanced when the firm's R\&D activities are based in locations where IPR protection is stronger. Moreover, when considering the internal geography of the MNEs R\&D activities, innovation performance depends on the distance between the home- and host-country IPR regime. Thus, innovation performance is worse, as the difference between home and host IPR regimes increases. Finally, we explore asymmetries in this relationship, in particular that the deterioration is more marked when MNEs locate their R\&D activities in host economies with IPR protection significantly less strict than in their home country. We test these ideas using a unique new dataset about the most innovative MNEs in the world, an unbalanced panel of around 900 MNEs observed for the period 2004 to 2013 and find strong support for all our hypotheses.

Journal of International Business Studies (2022) 53, 1945-1970.

https://doi.org/ | 0.1057/s41267-021-00452-z
\end{abstract}

Keywords: multinationals; innovation; IPR protection; institutional distance; patents; inventive capabilities

The online version of this article is available Open Access

\section{INTRODUCTION}

The international business (IB) literature has long seen the internationalization of innovation as a core research topic (Cantwell, 1989; Dunning, 1988; Narula, 2003). This is because highly innovative multinational enterprises (MNEs) possess an ownership advantage that can be exploited on overseas markets (Anand, McDermott, Mudambi, \& Narula, 2021; Cantwell, Dunning, \& Lundan, 2010; Rugman, 2009; Teece, 2007; Teece, 2014). Furthermore, research on cross-border innovation has been growing rapidly (Peng, Ahlstrom, Carraher, \& Shi, 2017), including with respect to networking activities (Cano-Kollmann, Cantwell, Hannigan, Mudambi, \& Song, 2016), innovation offshoring
Received: 24 January 2020

Revised: 6 May 2021

Accepted: 10 May 2021

Online publication date: 19 July 2021 
(Rosenbusch, Gusenbauer, Hatak, Fink, \& Meyer, 2019), as well as the impact of the legal environment (Brander, Cui, \& Vertinsky, 2017; Papageorgiadis, McDonald, Wang, \& Konara, 2020). This has led to significant developments in our understanding of the mechanisms underlying global innovation (Mudambi, 2008; Nandkumar \& Srikanth, 2016) and the internationalization of $\mathrm{R} \& \mathrm{D}(\mathrm{Pa}-$ panastassiou, Pearce, \& Zanfei, 2020).

Much of the IB literature about innovation focuses on location choices and the transfer of new knowledge from the point of creation to the point of use (Narula, 2014): R\&D subsidiaries may be located overseas for asset-seeking or augmenting reasons, for example to improve their existing assets by acquiring foreign research and science capabilities or to strengthen their existing assets by obtaining specific knowledge about new markets (Criscuolo, Narula, \& Verspagen, 2005). Thus, there is analysis of the recombination of resources and technological knowledge across locations ( Belderbos, Leten, \& Suzuki, 2013; Castellani, Jimenez, \& Zanfei, 2013); subsidiaries (Birkinshaw \& Hood, 1998); and boundaries (Kogut \& Zander, 1993). However, the impact of R\&D subsidiary - locations -the impact of decisions to internalise MNE innovation activities across boundaries- on innovation performance has rarely if ever been considered, especially for highly innovative MNEs. At the same time, the innovation literature has extensively explored the impact of the external environment on the process of knowledge diffusion (Audretsch \& Feldman, 2004), with IB scholars as well as economic geographers (e.g., Crescenzi \& Gagliardi, 2018; Crescenzi, Nathan \& Rodríguez-Pose, 2016) also stressing the role of institutional context in foreign direct investment (FDI) choices (Jackson \& Deeg, 2008; Li \& Zhou, 2017). Despite this, the relationship between MNE internal innovation performance, the geographic location of its $R \& D$ activities, and the institutional context, in particular, the strength of intellectual property rights (IPR) protection, has not yet been analyzed.

This research gap leads us to focus on three interrelated research questions about the effects of institutional context on the MNE internal innovation performance. First, we ask whether, given the internal geography of innovative capabilities across locations, innovation performance in highly innovative MNEs is stronger when more of its $R \& D$ activities are based in locations where there is stricter IPR protection. We go on to consider the effects of institutional distance on innovation performance, in particular concerning differences between home- and host-economy IPR regimes. Finally, we investigate possible asymmetries in those institutional distance effects, specifically whether the impact of IPR regime distance is the same when the home economy has strong IPR protection, and the host economy weaker, and when the home IPR regime is weak and the host economy stronger. Examples of such asymmetries are R\&D subsidiaries of developed economy MNEs located in emerging economies versus emerging economy MNE R\&D subsidiaries located in developed economies.

The IB literature has previously considered the impact of the IPR regimes on MNE strategies (Globerman \& Shapiro, 2002; Nandkumar \& Srikanth, 2016; Santangelo, Meyer, \& Jindra, 2016). Hence, the choice of FDI location has been found to be positively influenced by the strength of IPR protection: R\&D subsidiaries located in places where the protection of IPR is weak will find the fruits of innovation eroded by competitors' imitation of their products and technologies (Papageorgiadis et al., 2020). However, there is less research on the implications of heterogeneity in the IPR regime across $R \& D$ subsidiary locations. We argue that protecting, managing, and coordinating R\&D when some research subsidiary locations have lower IPR protection raises MNE costs of innovation and therefore weakens performance. This leads us to propose that MNE innovative performance will be better when its R\&D activities are concentrated in institutional contexts where IPR protection is stronger. Moreover, in addition to minimizing the transactions costs of generating a given level of knowledge, the MNE can learn more broadly from its knowledge creation in distant locations (Phene \& Almeida, 2008; Rugman \& Verbeke, 2001). In this respect, stronger IPR regimes will facilitate MNEs exploitation of dynamic capabilities (Nelson \& Winter, 1982; Teece, 2007, 2014) by "scanning, searching, and exploring changes and possibilities across technologies and markets, both local and distant" (Lee, Narula, \& Hillemann 2021).

Further, when considering the effects of the internal geography of MNE location decisions, we propose that MNE innovation performance will be sensitive to differences between the IPR regimes in the home and host countries. The base is set by MNEs whose internal R\&D activities are located in countries with similar IPR regimes, either strong IPR protection in both the home and host country 
or weak in both. When MNEs locate their R\&D activities in host economies with IPR regimes that are different from their home country, innovation performance is subject to distance effects. We argue that MNEs whose home R\&D facilities are located in low IPR protection countries find there to be additional information and coordination costs of managing knowledge creation in overseas settings. However, these may be offset by the lower costs of protecting their inventions when foreign $R \& D$ is located in strict IPR regimes, as well as by the benefits of learning from a different and possibly more technologically advanced host innovation environment (Rosenbusch, Gusenbauer, Hatak, Fink, \& Meyer, 2019). Even so, these costs will likely be higher than when they locate in low IPR protection regimes, because they have developed in their home economy a better understanding of knowledge management processes in institutionally challenging environments (Cuervo-Cazurra \& Ramamurti, 2014, 2017). In contrast, MNEs based in high IPR protection home countries have developed management systems to limit the costs of knowledge creation in strict IPR regimes, and find it more costly to pursue R\&D activities in low IPR protection environments because of the need to provide additional protection (e.g., secrecy) for the fruits of their work. Therefore, MNEs from low IPR countries investing in high IPR countries (e.g., Huawei locating R\&D facilities in Canada) will display - ceteris paribus - better innovation performance than MNEs from high IPR protection countries investing in locations with low IPR protection (e.g., Daimler doing R\&D in China). We test these ideas using a unique new dataset about the most innovative MNEs in the world, an unbalanced panel of around 900 firms observed for the period 2004 to 2013 and find strong support for our hypotheses.

We make several contributions to the IB literature. We use a firm-level analysis of MNE knowledge production process to explore the impact of the country-level institutional context on innovation performance. In particular, we investigate how innovation performance is affected by the strength of IPR, a framing consistent with other approaches to understanding the influence of institutions more broadly defined on MNE performance (Marano et al., 2016). Furthermore, we explore how innovation performance is affected by differences in home-host locations and by the distance between the strength of IPR protection in each. We show that distance effects are asymmetric: the negative impact of distance is more pronounced for firms based in strict IPR regimes located in less strict ones than for the converse. Finally, we exploit our dataset to provide results about the innovation performance of the most innovative firms in the world. By modeling the impact of the internal geography of the MNE knowledge creation process, we can empirically identify the sensitivity of innovation performance to the strength of the IPR regime; the distance between home and host economy, and how the latter effect depends on the strength of IPR regime in the host economy. Our findings have important implications for management practice in MNEs and for future research.

In the following section, we present our theoretical framework and our hypotheses, while the dataset is introduced in the third section. Methods and results are reported in section four and discussed in section five, while conclusions are drawn in the final section.

\section{HYPOTHESIS DEVELOPMENT}

\section{The Knowledge Production Function and Innovation Performance}

Our analysis studies the ways in which institutional context, in particular the strength of IPR protection, affects the innovation performance of MNEs whose R\&D efforts are internationalized. We focus on highly innovative MNEs, defined as firms that are heavily engaged in the research process, with their own teams of innovators undertaking research that leads to patents, and that typically undertake knowledge creation in a variety of different locations. Our notion of innovation performance concerns the productivity of the knowledge production process, which is the relationship between innovation inputs and output (Crescenzi \& Gagliardi, 2018; Griliches, 1979). Thus, we posit that MNEs transform research inputs, in particular the stock of inventive capabilities, into research outputs through a knowledge production technology which itself is contingent on the geographic location of research activities. Innovation performance is therefore defined in terms of the quantity of research output that the firm is able to generate from its internal inventive capability inputs.

The concept of inventive capabilities is defined by Arora, Cohen, \& Cunningham (2018) as "the upstream technical expertise and functions that allow firms to generate new products or improve existing products." (page 2). We also build on 
Leiponen and Helfat's (2010) work who associate inventive capabilities with internal human research capital and Marvel and Lumpkin (2007) who view inventive capability as describing the firms' endowment in innovative human capital. We argue that inventive capabilities, which we define as the stock of knowledge of inventors within a firm in a particular field of research, drive innovation by enabling the accumulation of specialized expertise and skills which the MNE uses in its internal knowledge creation process, for example in building new innovations on the basis of previous ones (Crossan \& Apaydin, 2010). High stocks of such knowledge, associated with deep enterprise-level inventive capabilities, allow the MNE to combine and recombine refinements in various aspects of processes and products (Christensen, 2006; Eisenhardt \& Martin, 2000; Teece, 2014). We therefore propose that MNEs with higher levels of internal inventive capability will generate more research output (see e.g., Hayton \& Zahra, 2005; Shrader \& Siegel, 2007). However, we posit that the relationship between inventive capability and innovation output is also sensitive to contextual factors associated with the geographic location of the inventive capabilities.

\section{Innovation Performance and IPR Regimes}

The literature has considered how MNEs choose locations for R\&D activities (Li \& Zhou, 2017) and produce innovation output across a variety of locations (Kotabe, Dunlap-Hinckler, Parente, \& Mishra, 2007; Lahiri, 2010). Our research goes on to consider the impact of the geographic distribution of MNE inventive capabilities on innovation performance, especially as a result of the heterogeneity in IPR protection across countries.

The IB literature has shown how institutional context influences various aspects of internationalization, including MNE strategy and performance (Jackson \& Deeg, 2008; Meyer \& Peng, 2016). While institutions influence many aspects of MNE decision-making, when considering innovation, perhaps the most important element of the institutional context is the strength of the IPR regime (Peng, Ahlstrom, Carraher, \& Shi 2017). This is because firms need not only to invent new products and processes but also to capture the surpluses thereby generated, and the strength of the IPR regime indicates the level of institutional protection provided to innovators through the legal system (Pisano \& Teece, 2007). Thus, where the IPR regime is strong, innovation is harder to imitate, and so competitors are less able to reduce or eradicate the firm-level competitive advantage bestowed as a result. In contrast, weak IPR protection may lead to underutilization of the firm's innovation capabilities (Zhao, 2006). The strength of IPR protection also affects FDI location (Khoury $\&$ Peng, 2011) with consequences on the overall distribution of foreign $R \& D$ activities.

So how does the strength of IPR protection influence the firm-level process whereby inventive capabilities are transformed into innovations across its R\&D locations? Our analysis is primarily based on an internal transactions' costs evaluation of impact of different property rights regimes on the knowledge production process (Casson, 1985). We propose that the costs of innovation to the MNE will be lower in locations where IPR protection is stronger. This is primarily because it is less complex and administratively demanding in such locations to protect the hard-won competitive advantage from imitation (Santangelo, Meyer, \& Jindra, 2016) and therefore the MNE does not have to incur a variety of additional costs to protect the knowledge creation process.

In contrast, the costs of achieving a given level of innovation performance will be higher in locations where IPR protection is weaker because the firm has to undertake additional and expensive activities to protect its innovation output. For example, in order to erect barriers to imitation, the firm may have to implement higher levels of internal security or follow more complex or convoluted research trajectories, which are harder to copy. In highly innovative MNEs with significant science and research establishments, these costs are likely to exceed any benefits from operating in an environment where the co-evolution of knowledge with competitors and hence learning is less costly (Rosenbusch et al., 2019). For these reasons, amongst others, Zhao (2006) argues that weak IPR protection has a generally dampening effect on innovation. Thus, the greater the extent to which innovation activities by MNEs are located in countries where IPR protection is weak, the lower will be innovation performance. This leads us to propose:

Hypothesis 1: MNE internal innovation performance will be stronger when innovation activities are predominantly located in countries with stricter IPR protection.

A complementary perspective to the transactions costs approach is offered by MNE 
internationalization strategies aimed at learning through asset seeking FDI (Criscuolo, Narula \& Verspagen, 2005). MNEs might benefit from internalizing spatially sticky and highly contextual localized knowledge in low IPR protection host locations. Furthermore, MNEs based in home economies with strict IPR regimes will be generally less likely to undertake R\&D in host locations with lower protection of their own knowledge assets due to the impeding effect of institutional distance, though they may still find it advantageous to access relatively less protected localized knowledge assets. A number of theoretical and empirical contributions have explored this trade-off in cross-border knowledge sourcing (see for example Papanastassiou, Pearce, \& Zanfei, 2020). This literature implies that, even if Hypothesis 1 is verified, MNEs may still locate their R\&D activities in locations with varying degrees of IPR protection, depending on their knowledge management and acquisition strategies. Hence, additional hypotheses are needed in order to better conceptualize the link between IPR regimes in the home and host economies, the internal MNE geography of inventive capabilities, and innovation performance. It is to these issues we turn in the next sub-sections.

\section{The Effects of Home-Host Differences in IPR Protection}

The IB literature has argued that the performance of MNEs is contingent, not only on the institutional quality of the host economy (Bevan \& Estrin, 2004; Globerman \& Shapiro, 2002) but also on the difference in institutional quality between home and host economies - institutional distance (Berry, Guillén, \& Zhou, 2010; Ghemawat, 2007; Kostova, Beugelsdijk, Scott, Kunst, Chua, \& van Essen, 2020). The fundamental idea is that transactions and other costs of MNE activities increase as locations are further away from the home economy in a variety of senses, including geographic, institutional, and contextual distance (Jackson \& Deeg, 2008; Kostova et al., 2020). We extend this concept to the analysis of internal knowledge in the MNE, by exploring the impact of different levels of strictness of IPR protection on innovation performance. We first consider the effects of distance (Beugelsdijk, Ambos, \& Nell, 2020) and in the next section turn to possible asymmetries in these effects (Shenkar, 2001; Zaheer, Schomaker, \& Nachum, 2012).

As noted above, MNEs internalize their innovation activities overseas to access foreign expertise as well as to increase the flexibility of their operations (Doh, Bunyaratavej, \& Hahn, 2009; Rosenbusch et al., 2019). For example, R\&D units may be located overseas to allow firms to better understand new markets or to exploit overseas science capabilities by choosing sites where there are large numbers of appropriately qualified and skilled researchers (Papanastassiou et al., 2020). However, the transactions costs lens suggests that there will be additional costs of creating, managing, and guiding research units in these overseas locations (Belderbos, R., Leten, B., \& Suzuki, 2013; Dachs, Stehrer, \& Zahradnik, 2014). These include the costs of ensuring that researchers are appropriately informed and knowledgeable about the nature of their products and customers in home markets; the costs of coordination between the headquarters and overseas units related for example to language and culture; and administrative costs arising from unfamiliarity with local rules and regulations, or from costs incurred to satisfy local social norms (Berry, 2014; Nandkumar \& Srikanth, 2016).

We have argued that a major factor underlying these costs is associated with deficiencies in the quality of institutions (Rosenbusch et al., 2019), among which, the strength of IPR regimes is perhaps the most important (Nandkumar \& Srikanth, 2016; Peng et al., 2017). However, these costs vary with institutional distance. Thus, in order for innovators to build on the knowledge and processes already undertaken in their $R \& D$ facilities, it is necessary for MNEs to provide their overseas research units with in-depth information about their production processes and their market positioning, much of this being imparted by direct communication and extended discussion (Cavusgil, Cantelone, \& Zhao, 2003). The costs of doing this will be higher between locations with greater differences in IPR regimes because barriers will have to be erected to limit the loss of that highly valuable knowledge from within the organization to competitors, for example through imitation of products or processes. Similarly, for continuous evolution of products and processes to ensure precise positioning within a market niche, this is a more costly exercise when the research activities are separated from the market-facing functions of the business and these costs are increased when there are greater differences in IPR regime because of the additional protections required internally when IPR protection is weaker (Castellani, Jimenez, \& Zanfei, 2013). Thus, greater distance between levels of IPR protection increase the costs of 
coordination between R\&D units (Blanc \& Sierra, 1999; Papanastassiou et al., 2020). Finally, greater IPR distance may raise the costs of transferring knowledge between overseas $\mathrm{R} \& \mathrm{D}$ subsidiaries and the parent organization or increase the costs of integrating that knowledge into the MNE routines and processes (Rosenbusch et al., 2019). Thus, for example, the understanding of subtle linguistic distinctions may compound difficulties caused by differences in social norms regarding for example the sharing of tacit knowledge or the willingness to learn from overseas groups with different characteristics concerning for example power-distance relationships or gender balance (Kogut \& Zander, 1993; Kshetri, 2007).

These costs of integration will be greater as differences between IPR protection in the home and host economies increase because of the additional complexity resulting from the need to operate simultaneously in different IPR regimes. For example, it may be increasingly expensive for managers based in strict IPR protection locations to get their research employees to understand and take seriously the imperative for the whole organization of protecting the knowledge creation process, requiring enhanced training and more sophisticated systems for managing knowledge flows. Barriers to restrict the loss of knowledge will become more expensive as distance between IPR regimes increases because of rising costs of learning and implementation, for example contracts, administration, and monitoring and legal fees. Thus, we argue that the informational, coordination, and administrative costs of managing overseas $\mathrm{R} \& \mathrm{D}$ subsidiaries increase as differences between the strictness of home and host IPR regimes increase. Hence, we propose:

Hypothesis 2: The positive relationship between inventive capabilities and innovation performance is less pronounced when the distance between the strictness of IPR protection in the home and host country is higher.

\section{Asymmetric Effects of Differences in Strictness of IPR Regime}

The IB literature has also argued that the effects of institutional distance are not necessarily symmetric. This is because one cannot assume the role of home and host institutions on strategic outcomes to be the same: as Shenkar (2001 p. 523) puts it, "home- and host-country effects are different in nature, the former being embedded in the firm while the latter is in a national environment." In the context of the internal geography of knowledge creation, it may therefore matter for the costs of managing internal $\mathrm{R} \& \mathrm{D}$ activities in different locations whether the MNE is based in a country with strict regulations, and is operating in countries with weaker ones, or the converse (Zaheer, Schomaker \& Nachum 2012).

We build on these ideas to propose that the impact of distance will be contingent on the starting point; the strictness of IPR regimes in the home country compared to that in the location of the R\&D subsidiaries. Hypothesis 2 argued that internal costs of information, coordination, and administration increase with IPR distance, but the extent of this increase is contingent on the strength of the IPR regime in the home country. Consider for example the costs of foreign $R \& D$ when MNEs from high IPR protection countries locate $R \& D$ subsidiaries in countries with similarly high levels of IPR protection, for example US MNEs undertaking research in the UK or Germany (Castellani et al., 2013). The similarity in the level of protection at home and abroad means that the various additional costs associated with undertaking $R \& D$ abroad will be limited. However, emerging economies (EEs) have become increasingly important as locations for offshoring R\&D (Baldwin \& Henkel, 2015; Santangelo et al., 2016) and some of these have less stringent IPR protection, generating the incremental costs of information, coordination, and administration discussed with reference to Hypothesis 2. The decision of MNEs from higher IPR protection economies to locate their innovation activities in lower IPR protection countries increases the distance between home and host economies in terms of IPR protection, thereby raising the cost of managing the knowledge creation process and lowering innovation performance. This is because the costs of ring-fencing and protecting MNE internal knowledge outweigh the potential benefits from strategic asset seeking offered by a weaker protection of localized knowledge in low IPR economies. For example, in low IPR countries, innovative (domestic and foreign) firms will put in place alternative strategies to protect their internal knowledge, limiting the scope for MNE learning and knowledge absorption.

However, these incremental costs will not be so great when we consider MNEs located in countries with low IPR protection managing $R \& D$ subsidiaries in countries with higher IPR protection. Institutional distance will still raise the costs of 
locating $R \& D$ abroad because the management systems and mechanisms of coordination designed to protect inventions in the low IPR home country will have to be adapted to fit stricter IPR protection. However, these costs will not be so pronounced as when the home country has a stricter IPR regime because the requirement to erect internal barriers to the flow of information is reduced; the MNE will need fewer mechanisms of its own to protect its inventions because more reliance can be placed on the national legal system and its enforcement. At the same time, an environment with well-protected IPR might also offer opportunities for knowledge absorption and external learning. For example, with a strong IPR regime protecting the outcome of their innovation process, local firms will be more open to engage in collective and interactive learning processes, offering MNEs opportunities for lowcost knowledge absorption (De Propris \& Driffield, 2006). Hence, we propose:

Hypothesis 3: The impact of differences in the IPR regime on the relationship between inventive capabilities and innovation performance within the MNE depends on the relative strictness of the IPR regime in the home and host countries.

\section{DATA}

Our empirical focus is on the world's most innovative MNEs, which largely innovate in-house. We gather and combine two independent data sources in order to test our hypotheses. First, we use publicly available patenting information provided by the United States Patent and Trademark Office (USPTO). This database provides information on knowledge generation globally because the US represents the largest market for firms to protect their intellectual property: hence, irrespective of their home country, MNEs have strong incentives to file their world-wide inventions with the USPTO. Moreover, because patents are filed for the same market and in a single patent office, the data are highly comparable across home and host countries. Each patent document contains a detailed description of the invention being patented, information about the type of technology it claims right to, the name(s) of the assignee(s) and inventor(s), and their place of residence. The database is regularly updated and therefore links inventors, their organizations, locations, and overall patenting activity, making it possible to capture the innovative performance of MNEs and the nature and diversity of their inventors.

Second, we use the information compiled in the Industrial R\&D Investment Scoreboard database. Since 2004, the Joint Research Centre and Research Directorate General at the European Commission produces a yearly report titled 'EU Industrial $R \& D$ Investment Scoreboard' (hereby referred to as 'Scoreboard'). The purpose of the report is to list and provide economic information about the companies in the world with the highest $R \& D$ spending. The database includes detailed information on total expenditure on $R \& D$ performed directly by each firm, but excluding $R \& D$ undertaken under contract for external entities such as government bodies or other companies. Other firm-level variables include sales and the number of employees. The 2500 companies listed in the 2017's Scoreboard account for more than 90\% of global business R\&D expenditure (Hollanders, EsSadki, Vértesy, \& Damioli, 2017).

In order to combine the firm-level information in Scoreboard with the patenting activity of these same firms at the USPTO, we manually matched company names in the Scoreboard database with those appearing in ORBIS. The ORBIS database is a commercial dataset that provides economic and administrative data for more than 130 million firms worldwide, including information about all patents granted to those firms by the USPTO. It thus provides a basis for matching the economic information in Scoreboard with their patenting activity at the USPTO. The details on the matching procedure are available from the authors upon request. The manual matching and cleaning process yielded an ORBIS unique identifier for 3123 Scoreboard firms. Our matching procedure uniquely identifies $98 \%$ of the Scoreboard, accounting for $96 \%$ of total combined R\&D expenditures, 2003-2016. We restrict our sample to Scoreboard firms that actively engage in patenting and that are MNEs. Our final estimation sample therefore comprises 879 Scoreboard companies that patented at least once at the USPTO and that have at least one fully controlled foreign subsidiary. This sub-sample of firms, comprising the world's highly innovative MNEs, was granted approximately 690,000 patents between 2004 and 2013 and account for $32.5 \%$ of patents granted at the USPTO over that period. 


\section{EMPIRICAL MODEL}

\section{Specification and Estimation}

Our empirical analysis uses the framework of the firm-level knowledge production function (Griliches, 1979). We follow the literature (e.g., Kotabe et al., 2007) in measuring innovation output by the number of patents per firm per annum; what Lazzarini, Mesquita, Montero, \& Musacchio (2021) call 'invention frequency'. Let $i$ denote firms in our sample, let $c=1, \ldots, 51$ denote the home country where each MNE is based, and let the temporal dimension be measured as 5-year period averages denoted for simplicity $t=2004, \ldots, 2013$. Then, the number of patents produced by the MNE can be specified as a function of firm-level inventive capabilities, IPR regime, and their interaction as well as other controls as follows:

$$
\begin{aligned}
\text { Innovation }= & \mathrm{f}(\text { IPR Regime, Inventive } \\
& \text { Capabilities, Inventive Capabilities }) . \\
& * \text { IPR Regime, Controls }
\end{aligned}
$$

We measure MNE inventive capabilities by the accumulated patenting experience of their inventors that forms the MNE Stock of knowledge, the average number of patents filed by the inventors associated with each MNE to that point in their career.

To consider the strictness of the IPR regime, we build on a dataset developed by Papageorgiadis, Cross, \& Alexiou (2014) and Papageorgiadis and Sofka (2020). The Patent Enforcement Index (PEI) 1998-2017 is a comprehensive measure built with the purpose of gauging the extent of "servicing costs", "property right costs", and "monitoring costs" at the country level around the world. It extends the patent protection index popularized by Park (2008). The PEI assumes values from 0 to 10, " 0 " being no protection at all and " 10 " being full protection. On this basis, we can identify the strictness of IPR regimes faced by the MNE in all the countries where the company locates its $R \& D$ activities, including the home country.

We use this to develop a measure of the MNE exposure to different intellectual property rights regimes in all countries (including in the home economy) as a consequence of the geographic distribution of its R\&D activities. Thus, we can define the firm-level patent enforcement index (FPEI):

$$
\begin{aligned}
& \text { Firm - Patent - Enforcement }- \text { Index }(F-P E I)_{i t c} \\
& =\omega_{i t c}^{1}\left(P E I_{t c}^{1}\right)+\omega_{i t c}^{2}\left(P E I_{t c}^{2}\right)+\cdots+\omega_{i t c}^{50}\left(P E I_{t c}^{50}\right) \\
& \quad+\omega_{i t c}^{51}\left(P E I_{t c}^{51}\right)
\end{aligned}
$$

where $\omega_{\text {itc }}{ }^{1}$ measures the proportion of patents located in country " $c$ " at time " $t$ " by the company " $i$ ", which must sum to one in each year: $\sum \omega_{i t c}{ }^{j} .=$ 1. The distribution of the firm-level patent enforcement index is reported in Figure 1.

In addition, we define a variable that measures the difference between MNE home IPR protection and the firm-level patent enforcement index compiled in Eq. (2). The Home-Host F-PEI distance measures the difference between the patent enforcement index in the MNE home country and the same index in all countries, including the home country, where the firm undertakes R\&D, F-PEI. The weights are given by the share of patents produced in each foreign country as shown in Eq. (2). Thus, the distance index is defined as:

$$
\begin{aligned}
& \text { Home Host } \mathrm{F}-\text { PEI Distance } \\
& =\text { Home }^{\text {PEI }} \mathrm{I}_{\mathrm{tcH}}-\text { Firm }- \text { Patent }- \text { Enforcement } \\
& \quad-\text { Index }_{\mathrm{itc}}
\end{aligned}
$$

where HomePEI $I_{t c H}$ is the patent enforcement index in the home (headquarters) country location of the company. Thus, the variable has a value of zero when the firm undertakes R\&D in foreign countries with the same level of IPR protection as its home country. The value will be positive when IPR protection in the home country is stricter than the

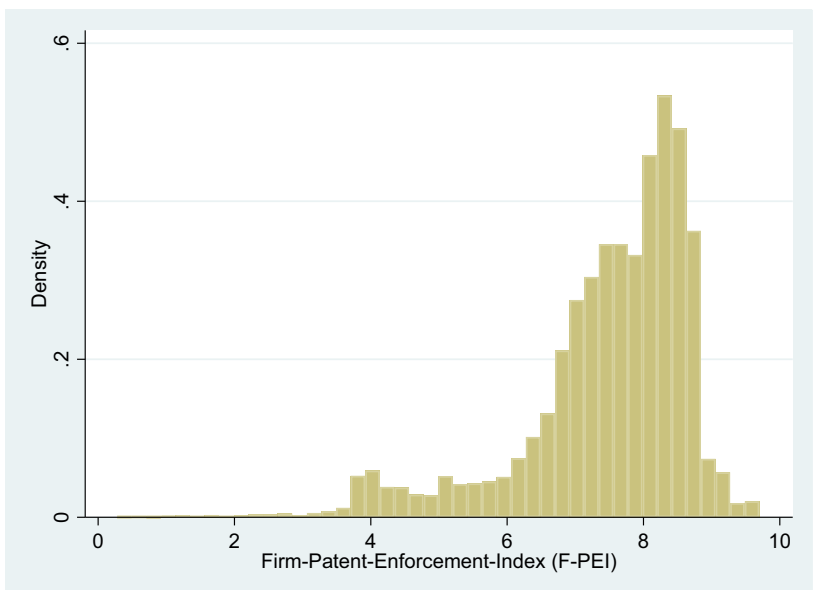

Figure 1 The firm-level patent enforcement index distribution. 
weighted average of that in the firm's other $R \& D$ locations: it is negative if the converse is true.

Firm controls include the standard firm-level 'knowledge production function' terms: the total number of inventors active in the firms (as a proxy for labor input in the innovation process) and total R\&D investment (as a proxy for capital input in knowledge production). The latter is also included in quadratic and cubic terms in order to control for non-linear effects. In addition, we control for other standard firm-level characteristics affecting innovation related to size and capital intensity, namely sales, total number of employees and capital investment. We also include firm fixed-effects $\left(\boldsymbol{\mu}_{\mathbf{i}}\right)$ and time fixed-effects $\left(\mathbf{t}_{\mathbf{t}}\right)$, as 5-year period dummies. The former controls for all time-invariant observable and unobservable characteristics of the firms; our longitudinal estimation models represent a very powerful specification because the firms' sector of activity, country of origin, intrinsic organizational structure, and company culture, among other things, are all controlled for in the regressions insofar as they are constant through time. This greatly reduces the potential omitted variable bias that occurs in pure cross-section data. Furthermore, we are able to account for a large proportion of the overall variability of the dependent variable in longitudinal models. The time fixed effects account for macroeconomic shocks common to all firms and all other factors that vary over time (including changes in the global patenting environment) for all firms.

In order to test Hypothesis 1, we include a set of interaction terms that capture the effects of the strength of the Firm-Patent-Enforcement-Index on the inventive capabilities-innovation performance relationship. The strength of the IPR regime is captured by the mean of the F-PEI, which in the first specification is converted into dummy variables based on critical threshold values selected looking at the distribution of the variable: "low" (for FirmPatent-Enforcement-Index $x_{\text {itc }}$ values between 0 and 6.95 ) is the (omitted) reference category, medium (dummy variable MEDIUM=1 when the Firm-Patent-Enforcement-Index ${ }_{i t c}$ ranges between 6.95 and 8.4) and "high" (dummy variable $\mathrm{HIGH}=1$ when the Firm-Patent-Enforcement-Index ${ }_{\text {itc }}$ exceeds 8.4). We therefore test Hypothesis 1 in Eq. (4):

$$
\begin{aligned}
\log \left(\mathrm{y}_{i t c}\right)= & \alpha_{0}+\alpha_{1} \log \left({\text { INVENTIVE CAPABILITIES })_{\mathrm{itc}}}\right. \\
& +\alpha_{2}\left[\mathrm{~F}-\mathrm{PEI}_{\mathrm{tc}}^{\mathrm{MEDIUM}} * \log (\text { INVENTIVE CAPABILITIES })_{\mathrm{itc}}\right] \\
& +\alpha_{3}\left[\mathrm{~F}-\mathrm{PEI}_{\mathrm{tc}}^{\mathrm{HIGH}} * \log (\text { INVENTIVE CAPABILITIES })_{\mathrm{itc}}\right] \\
& +\alpha_{4}\left(\mathrm{~F}-\mathrm{PEI}_{\mathrm{tc}}^{\mathrm{MEDIUM}}\right)+\alpha_{5}\left(\mathrm{~F}-\mathrm{PEI}_{\mathrm{tc}}^{\mathrm{HIGH}}\right) \\
& +\alpha_{6}\left(\mathrm{FIRM} \mathrm{CONTROLS}_{\mathrm{itc}}+\mathrm{t}_{\mathrm{t}}+\mu_{\mathrm{i}+} \varepsilon_{\mathrm{it}}\right.
\end{aligned}
$$

If Hypothesis 1 is supported, we would expect $\alpha_{3}>\alpha_{2}>0$, suggesting that in higher IPR regimes, firm-level inventive capabilities generate higher innovation output.

In a second specification, we test Hypothesis 1 specifying the Firm-Patent-Enforcement-Index $x_{i c c}$ as a continuous variable instead, as in Eq. (5):

$$
\begin{aligned}
\log \left(\mathrm{y}_{i t c}\right)= & \alpha_{0}+\gamma_{1} \log (\text { INVENTIVE CAPABILITIES })_{\mathrm{itc}} \\
& +\gamma_{2} \log (\text { INVENTIVE CAPABILITIES })_{\mathrm{itc}} \\
& * \text { Firm }- \text { Patent }- \text { Enforcement }- \text { Index }_{\text {itc }} \\
& +\gamma_{3} \text { Firm }- \text { Patent }- \text { Enforcement }- \text { Index }_{\text {itc }} \\
& +\gamma_{4}(\text { FIRM CONTROLS })_{\mathrm{itc}}+\mathrm{t}_{\mathrm{t}}+\mu_{\mathrm{i}+} \varepsilon_{\mathrm{itc}}
\end{aligned}
$$

For Hypothesis 1 to be supported, $\gamma_{2}$ should have a positive sign.

In order to test Hypothesis 2, we analyze the moderating effect of the difference between homehost IPR regimes on the relationship between inventive capabilities and MNE innovation. Therefore, in Eq. (6), we replace Firm-Patent-EnforcementIndex ${ }_{i t c}$ by the absolute value (indicated as $|.$.$| ) of$ the Home-Host F-PEI distance as defined by equation (3):

$$
\begin{aligned}
\log \left(\mathrm{y}_{i t c}\right)= & \beta_{0}+\beta_{1} \log (\text { INVENTIVE CAPABILITIES })_{\mathrm{itc}} \\
& +\beta_{2} \log (\text { INVENTIVE CAPABILITIES })_{\mathrm{itc}} \\
& * \mid \text { Home } \text { Host F }- \text { PEI Distance } \\
& +\beta_{3} \mid \text { Home }- \text { Host F }- \text { PEI Distance }{ }_{\mathrm{itc}} \mid \\
& +\beta_{4}(\text { FIRM CONTROLS })_{\mathrm{itc}}+\mathrm{t}_{\mathrm{t}}+\mu_{\mathrm{i}+} \varepsilon_{\mathrm{itc}}
\end{aligned}
$$

If Hypothesis 2 is supported, we would expect $\beta_{2} \neq 0$.

Finally, in Hypothesis 3, we posit that the effect of inventive capabilities on innovation performance is contingent on the direction of the difference in strictness of IPR regimes, whether positive or negative relative to the IPR strength of the home country where the headquarters is located. In order to test this hypothesis, we split the sample in two groups based on whether the difference in the 
Table 1 Testing Hypothesis 1. The moderating impact of IPR on inventive capabilities

\begin{tabular}{|c|c|c|c|}
\hline Dep: Patents per firm & $(1)$ & & $(2)$ \\
\hline Medium firm-patent-enforcement-index \# stock knowledge & $\begin{array}{l}0.137 \\
(0.031) \\
{[0.000]}\end{array}$ & Firm-patent-Enforcement-index\# Stock knowledge & $\begin{array}{l}0.140 \\
(0.026) \\
{[0.000]}\end{array}$ \\
\hline Top firm-patent-enforcement-index \# stock knowledge & $\begin{array}{l}0.305 \\
(0.075) \\
{[0.000]}\end{array}$ & & \\
\hline Stock knowledge & $\begin{array}{l}1.164 \\
(0.082) \\
{[0.000]}\end{array}$ & & $\begin{array}{l}0.236 \\
(0.198) \\
{[0.234]}\end{array}$ \\
\hline Middle firm-patent-enforcement-index & $\begin{array}{l}-0.262 \\
(0.058) \\
{[0.000]}\end{array}$ & Firm-patent-enforcement-index & $\begin{array}{l}-0.242 \\
(0.043) \\
{[0.000]}\end{array}$ \\
\hline Top firm-patent-enforcement-index & $\begin{array}{l}-0.545 \\
(0.127) \\
{[0.000]}\end{array}$ & & \\
\hline Inventors per firm & $\begin{array}{l}1.067 \\
(0.020) \\
{[0.000]}\end{array}$ & Inventors per firm & $\begin{array}{l}1.068 \\
(0.020) \\
{[0.000]}\end{array}$ \\
\hline$R \& D$ investment & $\begin{array}{l}-0.520 \\
(0.323) \\
{[0.108]}\end{array}$ & R\&D investment & $\begin{array}{l}-0.531 \\
(0.323) \\
{[0.100]}\end{array}$ \\
\hline$R \& D$ investment \# R\&D investment & $\begin{array}{l}0.112 \\
(0.065) \\
{[0.083]}\end{array}$ & $R \& D$ investment \# R\&D investment & $\begin{array}{l}0.113 \\
(0.064) \\
{[0.080]}\end{array}$ \\
\hline$R \& D$ investment \# R\&D investment \# R\&D investment & $\begin{array}{l}-0.008 \\
(0.004) \\
{[0.064]}\end{array}$ & $\begin{array}{l}\text { R\&D investment \# R\&D investment \# R\&D } \\
\text { investment }\end{array}$ & $\begin{array}{l}-0.008 \\
(0.004) \\
{[0.066]}\end{array}$ \\
\hline Sales & $\begin{array}{l}0.008 \\
(0.048) \\
{[0.876]}\end{array}$ & Sales & $\begin{array}{l}0.009 \\
(0.047) \\
{[0.856]}\end{array}$ \\
\hline Employees & $\begin{array}{l}-0.105 \\
(0.057) \\
{[0.069]}\end{array}$ & Employees & $\begin{array}{l}-0.105 \\
(0.056) \\
{[0.063]}\end{array}$ \\
\hline Capital & $\begin{array}{l}0.049 \\
(0.022) \\
{[0.024]}\end{array}$ & Capital & $\begin{array}{l}0.048 \\
(0.021) \\
{[0.024]}\end{array}$ \\
\hline Constant & $\begin{array}{l}-0.331 \\
(0.542) \\
{[0.542]}\end{array}$ & Constant & $\begin{array}{l}1.269 \\
(0.610) \\
{[0,071]}\end{array}$ \\
\hline Observations & 6,052 & Observations & 6,052 \\
\hline Number of firms & 879 & Number of firms & 879 \\
\hline Adjusted R-squared & 0.860 & Adjusted R-squared & 0.862 \\
\hline Firm FE & YES & Firm FE & YES \\
\hline Year FE & YES & Year FE & YES \\
\hline
\end{tabular}

Robust standard errors are in "( )" parentheses and $p$ values are in "[ ]" brackets. Note: Column 1. Omitted Firm-patent-enforcement-index category "low" protection (below 6.95 on a 0-10 scale, see text).

strictness of IPR regime between the home and host economy is positive or negative. We test whether the coefficient on distance, $\beta_{2}$, is the same in each sub-sample. In the Appendix, we also specify a triple interaction model where the impact of inventive capability is moderated by absolute value of the |Home-Host F-PEI Distance| and by the direction of the distance. We use these results to plot 3-D contour maps of the distance effects in the Discussion section.

In our models, standard errors are clustered at the firm level in order to incorporate within-firm 
correlations and we adopt a log-log specification, so the interpretation of the coefficients is therefore in terms of elasticities. We report the correlation coefficients and the Variance Inflation Factors (VIF) in the Appendix.

\section{Results}

In Table 1, we report the estimates of Eqs. (4) and (5) using two-way (firm and year) fixed-effects panel data methods. Column 1 reports the results using dummy variables for low (omitted) medium and high values of the F-PEI as in Eq. (4) and column (2) shows the F-PEI index as a continuous variable as in Eq. (5).

Hypothesis 1 explores the moderating effect of the strength of the IPR regime on the relationship between inventive capabilities and innovation output and we find strong support for it in Table 1. In column (1) we find $\alpha_{3}>\alpha_{2}>0$, with the $p$ values of both coefficient equal to 0.000 as well as being different from each other. In column (2), we find $\gamma_{2}>0$, with $p$ value 0.000 . Thus, MNEs whose geographic location of $R \& D$ facilities is more intensively located in countries with higher IPR protection have enhanced innovative performance vis-à-vis those in lower IPR protection regimes.

Hypothesis 2 concerns the moderating effect of the difference (distance) between home-host IPR regimes on the relationship between inventive capabilities and innovation output. It is tested in Eq. (6), the estimates of which are reported in Table 2. If Hypothesis 2 is supported, we expect to identify a significant (moderated) effect of distance on innovative performance.

In Table 2, we find strong support for Hypothesis 2: the coefficient on the interactive term, (Stock

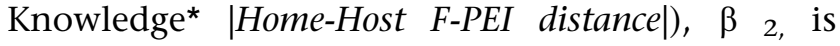
significantly different from zero with $p$ value 0.000 . Since, as we noted in our specification of Home-Host F-PEI distance in Eq. (3), our measure of distance can take either negative or positive values, because in our formulation distance could increase in a positive or a negative direction. In fact, the coefficient is found to be negative. Inventive capabilities enhance innovation output more when |Home Host F-PEI Distance| (the absolute value of the difference in IPR protection between the MNE home country and F-PEI), is exactly 0 . In fact, Hypothesis 3 explores the possibility that the moderating effects of F-PEI distance on innovation are asymmetric. In Table 3, we split the sample into two sub-samples to re-estimate Eq. (6): one where the value of Home-Host F-PEI distance is positive and
Table 2 Testing Hypothesis 2. The role of absolute home-host patent enforcement index distance

\begin{tabular}{|c|c|}
\hline \multicolumn{2}{|l|}{ Dep: Patents per firm } \\
\hline Stock knowledge\# |Home-Host F-PEI distance| & $\begin{array}{l}-0.143 \\
(0.039) \\
{[0.000]}\end{array}$ \\
\hline Stock knowledge & $\begin{array}{l}1.375 \\
(0.086) \\
{[0.000]}\end{array}$ \\
\hline |Home-host F-PEI distance| & $\begin{array}{l}0.265 \\
(0.063) \\
{[0.000]}\end{array}$ \\
\hline Inventors per firm & $\begin{array}{l}1.064 \\
(0.020) \\
{[0.000]}\end{array}$ \\
\hline$R \& D$ investment & $\begin{array}{l}-0.637 \\
(0.300) \\
{[0.034]}\end{array}$ \\
\hline$R \& D$ investment \# $R \& D$ investment & $\begin{array}{l}0.136 \\
(0.060) \\
{[0.024]}\end{array}$ \\
\hline $\begin{array}{l}R \& D \text { investment \# R\&D investment \# R\&D } \\
\text { investment }\end{array}$ & $\begin{array}{l}-0.009 \\
(0.004) \\
{[0.020]}\end{array}$ \\
\hline Sales & $\begin{array}{l}0.002 \\
(0.051) \\
{[0.969]}\end{array}$ \\
\hline Employees & $\begin{array}{l}-0.104 \\
(0.060) \\
{[0.083]}\end{array}$ \\
\hline Capital & $\begin{array}{l}0.047 \\
(0.022) \\
{[0.036]}\end{array}$ \\
\hline Constant & $\begin{array}{l}-0.510 \\
(0.522) \\
{[0.329]}\end{array}$ \\
\hline Observations & 6,023 \\
\hline Number of unique BVD identifiers & 874 \\
\hline Adjusted R-squared & 0.865 \\
\hline Firm FE & YES \\
\hline Year FE & YES \\
\hline Country-year FE & YES \\
\hline
\end{tabular}

Robust standard errors are in "( )" parentheses and $p$ values are in "[ ]" brackets.

one where it is negative. The hypothesis is supported if the estimates of coefficient $\beta_{2}$ are different in the two sub-samples.

In Table 3, columns (1) and (2), we report the pair of split sample regressions of Eq. (6) for positive and negative distance respectively (zero distance is included in the positive distance sub-sample). Positive distance entails the allocation of R\&D activities to countries with lower PEI, and viceversa for negative distance. Table 3 provides strong 
support for Hypothesis 3 in that the coefficient $\beta_{2}$ is negative and significant with $p$ value 0.000 for the positive distance subsample but positive, though insignificant ( $p$ value 0.506), for the negative distance sub-sample. Thus, we find that the moderating effects of distance are asymmetric: they are negative when MNEs locate their innovation activities in countries with less strict IPR rules but insignificant when they are located in countries with stricter rules.

The use of sub-samples opens the possibility that the results are driven by the low sample size; there are only 290 companies for which distance is negative as against 783 for which it is positive. Moreover, the sample splitting around zero distance is not exactly the same as one in which the

Table 3 Testing Hypothesis 3. The role of absolute distance and its direction (via sample split)

\begin{tabular}{|c|c|c|c|c|}
\hline Dep: patents per firm & $(1)$ & $(2)$ & (3) & (4) \\
\hline & $\begin{array}{l}\text { Positive (or zero) } \\
\text { distance }\end{array}$ & $\begin{array}{l}\text { Negative } \\
\text { distance }\end{array}$ & $\begin{array}{l}\text { High home patent } \\
\text { enforcement index }\end{array}$ & $\begin{array}{l}\text { Low home patent } \\
\text { enforcement index }\end{array}$ \\
\hline \multirow{3}{*}{$\begin{array}{l}\text { Stock knowledge\# |Home-Host } \\
\text { F-PEI distance| }\end{array}$} & -0.157 & 0.075 & -0.169 & -0.084 \\
\hline & $(0.040)$ & $(0.113)$ & $(0.040)$ & $(0.104)$ \\
\hline & {$[0.000]$} & {$[0.506]$} & {$[0.000]$} & {$[0.421]$} \\
\hline \multirow[t]{3}{*}{ Stock knowledge } & 1.426 & 0.875 & 1.387 & 1.176 \\
\hline & $(0.093)$ & $(0.202)$ & $(0.098)$ & $(0.141)$ \\
\hline & {$[0.000]$} & {$[0.000]$} & {$[0.000]$} & {$[0.000]$} \\
\hline \multirow[t]{3}{*}{ |Home-Host F-PEI distance| } & 0.291 & -0.177 & 0.302 & 0.187 \\
\hline & $(0.064)$ & $(0.143)$ & $(0.065)$ & $(0.164)$ \\
\hline & {$[0.000]$} & {$[0.217]$} & {$[0.000]$} & {$[0.254]$} \\
\hline \multirow[t]{3}{*}{ Inventors per firm } & 1.073 & 1.025 & 1.080 & 1.007 \\
\hline & $(0.022)$ & $(0.057)$ & $(0.023)$ & $(0.033)$ \\
\hline & {$[0.000]$} & {$[0.000]$} & {$[0.000]$} & {$[0.000]$} \\
\hline \multirow[t]{3}{*}{$R \& D$ investment } & -1.122 & -0.302 & -0.812 & -0.415 \\
\hline & $(0.348)$ & $(0.609)$ & $(0.389)$ & $(0.369)$ \\
\hline & {$[0.001]$} & {$[0.620]$} & {$[0.037]$} & {$[0.261]$} \\
\hline \multirow{3}{*}{$\begin{array}{l}\mathrm{R} \& \mathrm{D} \text { investment \# R\&D } \\
\text { investment }\end{array}$} & 0.226 & 0.078 & 0.160 & 0.113 \\
\hline & $(0.068)$ & (0.139) & $(0.076)$ & $(0.082)$ \\
\hline & {$[0.001]$} & {$[0.574]$} & {$[0.036]$} & [0.168] \\
\hline \multirow{3}{*}{$\begin{array}{l}R \& D \text { investment \# R\&D } \\
\text { investment \# R\&D investment }\end{array}$} & -0.014 & -0.007 & -0.010 & -0.010 \\
\hline & $(0.004)$ & $(0.011)$ & $(0.005)$ & $(0.006)$ \\
\hline & {$[0.001]$} & {$[0.515]$} & {$[0.034]$} & [0.098] \\
\hline \multirow[t]{3}{*}{ Sales } & 0.003 & -0.001 & -0.032 & 0.117 \\
\hline & $(0.052)$ & $(0.085)$ & $(0.060)$ & $(0.056)$ \\
\hline & {$[0.960]$} & [0.992] & [0.589] & {$[0.0 .39]$} \\
\hline \multirow{3}{*}{ Employees } & -0.122 & -0.052 & -0.072 & -0.164 \\
\hline & $(0.067)$ & $(0.092)$ & $(0.076)$ & $(0.064)$ \\
\hline & [0.069] & {$[0.571]$} & {$[0.341]$} & {$[0.011]$} \\
\hline \multirow[t]{3}{*}{ Capital } & 0.064 & -0.029 & 0.052 & 0.046 \\
\hline & $(0.024)$ & $(0.044)$ & $(0.029)$ & $(0.025)$ \\
\hline & {$[0.008]$} & [0.517] & {$[0.074]$} & [0.069] \\
\hline \multirow[t]{3}{*}{ Constant } & 0.247 & -0.158 & -0.255 & -0.665 \\
\hline & $(0.605)$ & $(0.978)$ & $(0.680)$ & $(0.664)$ \\
\hline & [0.683] & {$[0.871]$} & [0.708] & {$[0.317]$} \\
\hline Observations & 5,155 & 868 & 3,965 & 2,058 \\
\hline Number of unique BVD identifiers & 783 & 290 & 735 & 604 \\
\hline Adjusted R-squared & 0.865 & 0.869 & 0.867 & 0.872 \\
\hline Firm FE & YES & YES & YES & YES \\
\hline Year FE & YES & YES & YES & YES \\
\hline Country-year FE & YES & YES & YES & YES \\
\hline
\end{tabular}

Robust standard errors are in " () " parentheses and $p$ values are in "[ $]$ " brackets. 
home country has high, or low, IPR protection. To ensure these factors are not affecting our results, we therefore also report a robustness test in Table 3, columns (3) and (4), in which we again use a sample split, but this time on the basis of the level of IPR protection in the home country, taken at the median, namely high PEI countries versus low PEI ones. This generates a more equal balance of firms in the two sub-samples: 735 MNEs in the category of high home-country PEI and 604 countries where the home-country PEI is low. Hypothesis 3 is also strongly supported in this specification: the coefficient $\beta_{2}$ is once again negative and significant with $p$ value 0.000 for countries in where IPR protection is strong, and insignificant ( $p$ value 0.421 ) in countries in where it is weak. We report results based on a triple interaction model, also supportive of Hypothesis 3, in the Appendix.

\section{DISCUSSION}

A large amount of literature has explored how IPR regimes have affected the location choices of MNE R\&D activities (Khoury \& Peng, 2011; Lahiri, 2010; Papageorgiadis et al., 2020a; Santangelo et al, 2016) as well as the impact of IPR regimes on innovation output (Rosenbusch et al., 2019; Zhao, 2006). Our analysis takes a rather different angle. It considers how MNE innovation performance is affected by the internal geography of the firm's knowledge creation resources and their institutional context. Thus, we consider the firm-level relationship between the MNE (geographically spread) inventive capabilities, the institutional environment in the relevant home and host economies, and its innovation output. In particular, we explore the impact of differences in the strength of IPR protection between the various locations in which the MNE undertakes $\mathrm{R} \& \mathrm{D}$ on innovation performance, including distance effects and whether they are symmetric.

Our analysis is based on a knowledge production model in which innovation output is associated with the inventive capabilities of researchers, measured by the research stock of the inventor group; we term this relationship innovation performance. We first propose that MNEs whose R\&D activities are concentrated in countries with higher IPR protection will display superior innovation performance.

Our empirical work is based on a dataset which allows us to identify where MNEs undertake their $\mathrm{R} \& \mathrm{D}$, as well as the resource inputs and outputs in

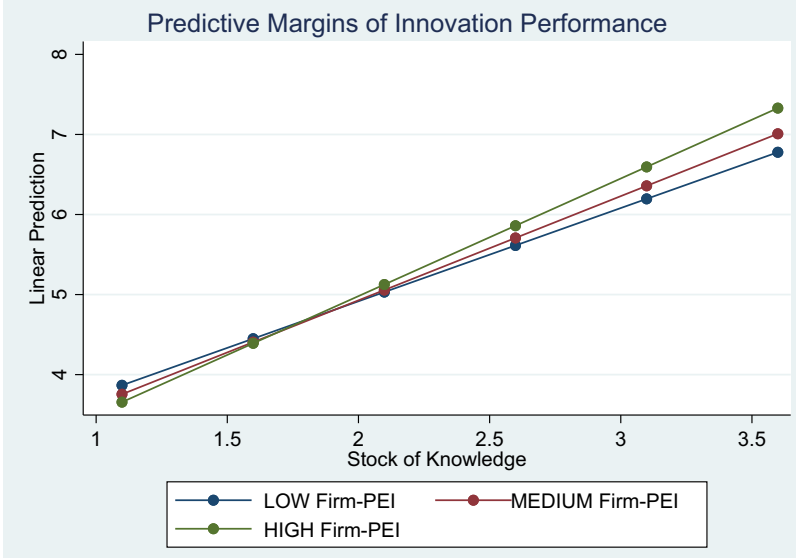

Graph 1 Patent Enforcement Index marginal effects (Table 1 column 1).

each location. We find strong support for the first hypothesis in the data, using both a continuous measure of distance and when we group countries into three categories according to the strength of the IPR regime. We plot the latter model in Graph 1 , which is based on Column (1) of Table 1. This shows that MNEs whose R\&D activities are based in locations of middle IPR protection show superior innovation performance to those with regimes of lower protection. Moreover, MNEs with innovation activities in locations of high IPR protection display higher innovation performance than those in the middle and especially the lower, category. The latter effects (high compared to middle) are more pronounced than for middle compared to low IPR protection. This suggests that MNEs gain most in terms of innovation performance when their $R \& D$ subsidiaries are primarily or entirely located in the highest IPR protection regimes. It is also interesting to note that there is no positive effect from the strength of IPR rules below a certain, quite low threshold in terms of the inventive capability of the firm. This suggests that the strength of IPR protection does not affect innovation performance for technologically unsophisticated MNEs: the consequences of potential knowledge seepage to competitors only begins to have consequences in terms of costs when the firm has a certain level of knowledge capability to protect.

For completeness, we also plot in Graph 2 the continuous F-PEI model of Eq. (5), reported in Column (2) of Table 1. We therefore use a Margins 3-D plot in Graph 2 with inventive capability (stock of knowledge) on the $x$-axis, firm-level IPR protection (F-PEI) on the $y$-axis, and innovation output 


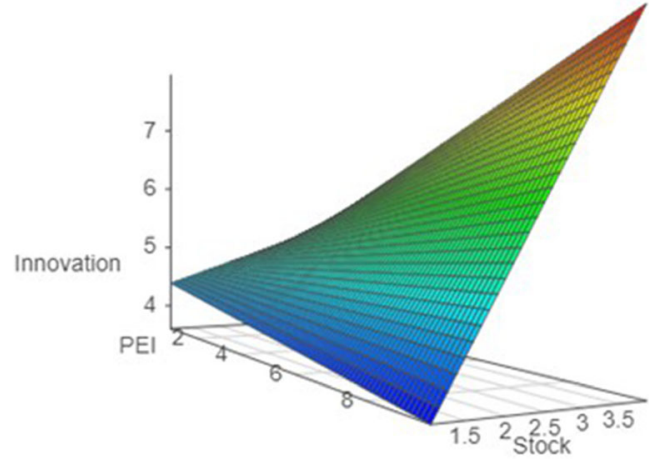

Graph 2 Margins 3-D plot: (Table 1 column 2). The three numbers at the vertices of the parallelepiped are respectively: (a) 1 st number, the minimum (1.10) and the maximum (3.60) values of stock of knowledge ( $x$-axis); (b) 2nd number, the minimum (3.64) and the maximum (7.38) values of innovation performance (z-axis); Dark blue dots indicate low innovation performance (towards the minimum), green dots indicate signal intermediate levels, and the red dots indicate high innovation performance (towards the maximum). (c) 3rd number, the minimum (0.50) and the maximum (9.00) values of firm-patentenforcement-index ( $y$-axis).

on the third vertical dimension (z-axis). The findings are consistent with Graph 1: as F-PEI increases, the relationship between inventive capability and innovation output becomes more positive, and hence the 3-D Margins plot becomes rounded in the top right-hand corner of the graph (high stock combined with high protection). It will be remembered that our sample comprises highly innovative MNEs with significant numbers of scientific workers geographically distributed in subsidiaries across the world. These results suggest that for such firms, the negative impact of informational, coordination and administrative costs of managing overseas $R \& D$ subsidiaries in locations with weaker IPR protection outweigh any potential benefits in terms of learning from the less restricted transmission of knowledge in such contexts. In terms of learning and knowledge management, this evidence is also in line with the strategic management insights offered by Alcácer and Chung (2007) and Cassiman and Veugelers (2002), whereby firms consider not only gains from inward knowledge spillovers but also the possible cost of outward spillovers. Technological leaders have least to gain (given their leadership position) and most to lose (given the potential for knowledge leakages) when locating their R\&D activities in low IPR host locations.
We find our estimates of the knowledge production function in Table 1 to be highly robust across specification. We also control for numerous timevarying firm-level factors such as R\&D expenditure, firm size, and capitalization. Thus, innovation output is found to be positively affected by other innovation inputs, namely the number of inventors and R\&D expenditures, the latter in a nonlinear way. Sales are found not to matter for innovation performance, so large firms are equally able to patent as small ones, though capital intensity is important; innovation output is greater as capital intensity increases. The estimation was undertaken within a panel fixed effects framework that controlled for both firm level and time period heterogeneity. These firm and year fixed effects control for all time-invariant characteristics of firms and their innovation infrastructure, including sector of economic activity, technological intensity, and location, as well as for time-specific technological shocks or events that might affect patenting output.

Of course, support for Hypothesis 1 does not imply that MNEs will only locate R\&D subsidiaries in jurisdictions with strong IPR protection. This is because, as we have seen, there are a variety of ways in which different host countries can bring advantages to the internal knowledge production process (Rosenbusch et al., 2019). For example, overseas locations may be attractive bases for $R \& D$ subsidiaries because they provide access to agglomerations of (relatively cheap) highly skilled labor or products, as in the availability of software engineers around Bangalore in India (Lewin, Massini, \& Peeters, 2009); because they provide a deeper understanding of consumer tastes in key markets (Cote, Estrin, \& Shapiro, 2020a, 2020b); as well as because of their lower overall costs, for example in Brazil or Thailand (Minbaeva, Pederson, Bjorkman, $\&$ Fey, 2014). However, our findings temper those benefits: when choosing locations in which IPR protection is weak, MNEs need to be aware this comes at a cost in terms of innovation performance.

The IB literature has also previously found that overseas R\&D facilities face higher costs (Belderbos et al., 2013; Berry, 2014; Nandkumar \& Srikanth, 2016). Our contribution is to show these costs are context-specific, being conditional on the geographical location of the MNEs R\&D activities, and sensitive to institutional quality, in particular the strength of IPR protection. We find that innovation performance of MNEs disproportionately 
located in lower IPR protection regimes will be worse and argue that this is a consequence of the resulting higher costs of transmitting information, as well as coordination and administration of inventors. For example, when more R\&D facilities are located where IPR protection is weaker, the firm must do more to protect its discoveries, and this places costly constraints on the free flow of information within the organization. Thus, when IPR protection is weak, the MNE needs to erect complex barriers to the inward flow of knowledge from other $\mathrm{R} \& \mathrm{D}$ facilities to prevent its imitation or loss. Moreover, we propose that the scale of these additional costs will depend on the difference between the IPR regime in the home and host economies: we argue in Hypothesis 2 that innovation performance will be worse as the differences in the strength of IRP protection between home and host economies are greater.

Our test of Hypothesis 2 is in Table 2, where we find strong support for the hypothesis; the coefficient on the interactive term between the stock of knowledge and distance is negative and significant at the 99\% level. Thus, as distance between IPR regime in the home and the weighted average of the host countries in which the firm undertakes $R \& D$ increases, the impact of inventive capabilities on innovation performance is reduced. We plot this relationship in Graph 3, which shows a Margins 3-D plot of this relationship. As hypothesized, we find that the highest innovation performance is characterized by high values of stock of knowledge and low (possibly 0) F-PEI distance.

We associate this finding with higher cost of managing and coordinating knowledge exchange between R\&D units within the MNE as IPR regimes become more different. For example, for MNEs based in high IPR protection locations, the costs of erecting barriers to prevent learning by competitors from their own knowledge creation in locations with lower IPR protection will be higher as that protection declines while the administrative costs of coordinating between the different $R \& D$ locations is also higher. Firms in low IPR protection locations face the same problem in reverse: the costs of knowledge protection, as well as coordination and administrative costs, are greater as the differences in home-host IPR protection is larger.

These results extend the domain of issues in IB that are affected by differences between home and host economies. The literature has already established the significance of the distance concept, for example in explaining trade flows and FDI location (Cote et al., 2020a, 2020b). Moreover, the concept of distance has been extended from its original framing in terms of geographic distance (Blanc-Brude, Cookson, Piesse, \& Strange, 2014) to include much broader notions such as institutional distance (Kostova et al., 2020). However, the impact of distance has rarely been applied to the internal architecture of the MNE. Our analysis is focused on the internal geography of the MNE, and explores the impact of institutional distance, indicated by the strength of IPR protection in different locations, on the firm's innovation performance. Our results show that MNE performance in innovation is sensitive to the institutional characteristics of the locations in which $R \& D$ activities are based, and in particular to the distance in terms of IPR protection between the home and host economies. Thus, MNE managers considering overseas locations for R\&D subsidiaries need to take account, not only of the IPR regime in the host economy in question, but also of the difference between the IPR protection there in comparison with their domestic base.

Unlike costs arising from geographic distance, which are likely the same whether measured from the home or the host economy, Shenkar (2001) argued that when we conceptualize the effects of institutional distance, it may matter which is the host and which is the home economy. For example,

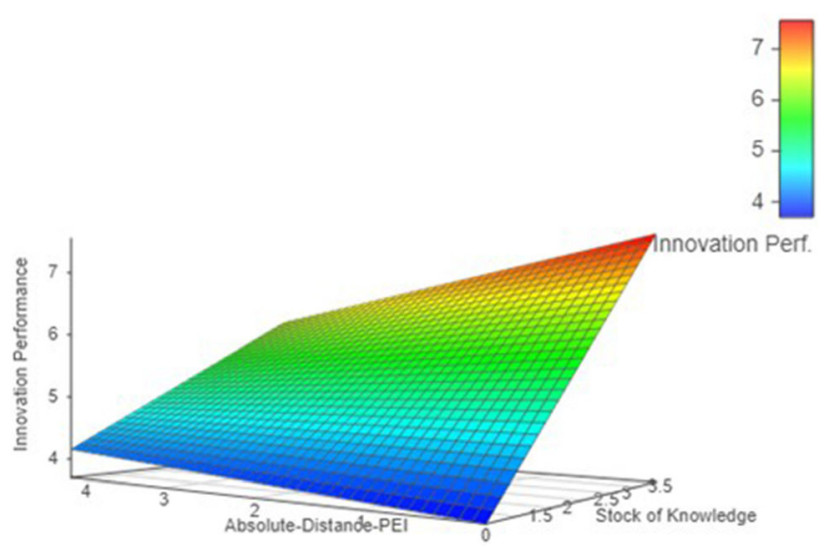

Graph 3 Margins 3-D plot: (Table 2). The three numbers at the vertices of the parallelepiped are respectively: (a) 1st number, the minimum (1.10) and the maximum (3.90) values of stock of knowledge ( $x$-axis); (b) 2nd number, the minimum (3.70) and the maximum (7.55) values of innovation performance ( $z$-axis); dark blue dots indicate low innovation performance (towards the minimum), green dots indicate signal intermediate levels, and the red dots indicate high innovation performance (towards the maximum). (c) 3rd number, the minimum (0.00) and the maximum (4.20) values of absolute distance of firm-patentenforcement-index ( $y$-axis). 
it may be more difficult, and therefore more costly, to move from culture A to culture $B$, than vice versa. In Hypothesis 3, we extend this idea to the geographic location of the MNE knowledge creation process. To be precise, we propose that it would be more costly for firms in high IPR protection regimes to locate $R \& D$ activities in low IPR protection locations than the converse. This was because MNEs based where IPR protection was strong would need to incur considerable costs to understand and erect barriers against the loss of knowledge in $R \& D$ subsidiaries in locations with low IPR protection. In contrast, MNEs based in locations with low IPR protection, which had already developed administrative structures to protect the intellectual property created by the innovation process, would find it less costly to administer and coordinate their invention activities if they moved to stricter IPR protection locations. Moreover, these cost differences would become more marked as the distance between home and host became greater. This is because as distance increases for the high IRP protection based MNE, the strength of IPR protection is declining and the costs of ameliorating that deterioration will increase. In contrast, for the low IPR protection based MNE, increased distance implies the selection of locations with increasingly more stringent IPR protection, making it even easier to safeguard the knowledge created in those jurisdictions.

We find strong evidence of these asymmetric distance effects in Table 3. MNEs for which the weighted average level of IPR protection was higher in the host than the home countries (positive distance) had an inferior innovation performance as IPR distance increased. On the other hand, innovation performance was actually found to be superior in MNEs in which the weighted average level of IPR protection was lower in the host than the home country (negative distance), though not significantly so. The difference between the distance effects in the positive and negative direction of IPR distance was statistically significant at the 99\% level.

An alternative way to consider the different effects of positive and negative distance is to use the fully interacted model, with results reported in the Appendix. We illustrate these results in Graphs 4 and 5, based on the Table 6 column (1): Graph 4a is drawn for positive IPR distance and Graph $4 \mathrm{~b}$ for negative IPR distance. The graphs show inventive capability on the $y$-axis and the difference in home-host IPR protection on the $y$-axis, with the

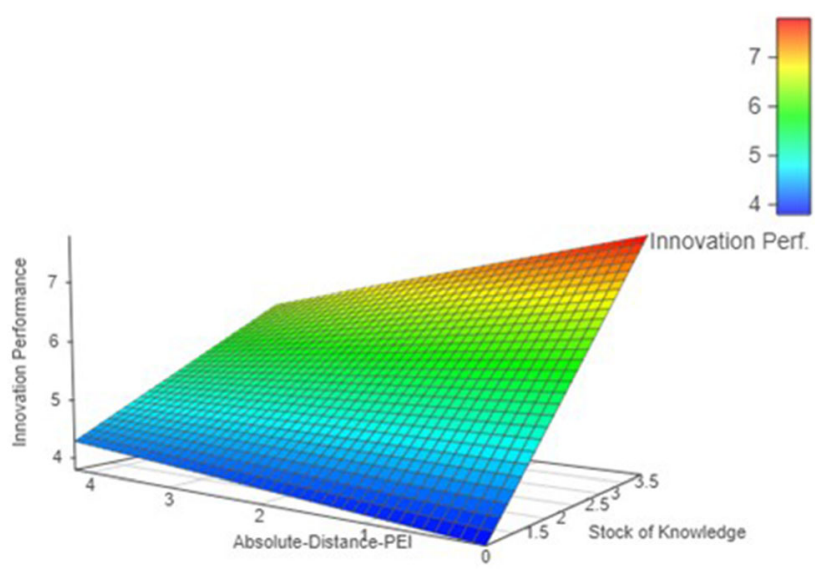

Graph 4a Margins 3-D plot: (Table 6 column 1 if positive distance dummy=1). The three numbers at the vertices of the parallelepiped are respectively: (a) 1st number, the minimum (1.10) and the maximum (3.90) values of stock of knowledge ( $x$ axis); (b) 2nd number, the minimum (3.71) and the maximum (7.53) values of Innovation Performance (z-axis); dark blue dots indicate low innovation performance (towards the minimum), green dots signal intermediate levels, and red dots indicate high innovation performance (towards the maximum). (c) 3rd number, the minimum (0.00) and the maximum (4.20) values of absolute distance of firm-patent enforcement-index ( $y$ axis).

3-D vertical axis representing innovation output. The difference between the negative and positive distance is highlighted by comparing the two figures. In Graph 4a, innovation output is highest in the top left-hand corner, where inventive capability is high and distance low. Output declines with both with inventive capability and distance. However, the impact of distance on performance is much weaker for the negative IPR sub-sample (where IPR protection in the home economy is low). Thus, in Graph 4b innovation output rises with inventive capability, but is only very slightly associated with distance, decreasing marginally when capability is high.

We can identify two situations in which the MNE will have low distance across its $R \& D$ subsidiaries in IPR protection: because both the home and host economy have strong IPR protection or because they both have weak protection. In both cases, we would argue that there will only a modest (negative) effect on the relationship between inventive capabilities and innovation performance because the firm does not have to operate very differently abroad from at home; the incremental costs of knowledge creation abroad will be modest, but there are also two cases in which the MNE has high distance in IPR protection. The first is when a firm located in a strong IPR protection economy locates 
its $R \& D$ facilities in a weak IPR protection countries, perhaps to benefit from lower labor costs or an agglomeration of technical skills, as for software companies in South India (Rosenbusch et al., 2019). The second is when MNEs from weak IPR protection countries locate their research facilities in strong IPR protection locations, perhaps to exploit technological know-how and reduce the risk of low appropriability (Cuervo-Cazurra \& Ramamurti, 2017). There are numerous examples of such strategic decisions, especially in the automobile sector where manufacturers such as Volkswagen have created innovation centers in China to exploit expertise in battery development (Global EV Report, 2020).

In both cases, the distance in IPR protection will be relatively high and there will be more pronounced negative effects on innovation performance than when locating in jurisdictions where IPR protection is similar. However, our empirical work has established that when IPR distance is higher, the effects in these two cases is not symmetric: the negative effect on innovation performance will be larger in the first than the second

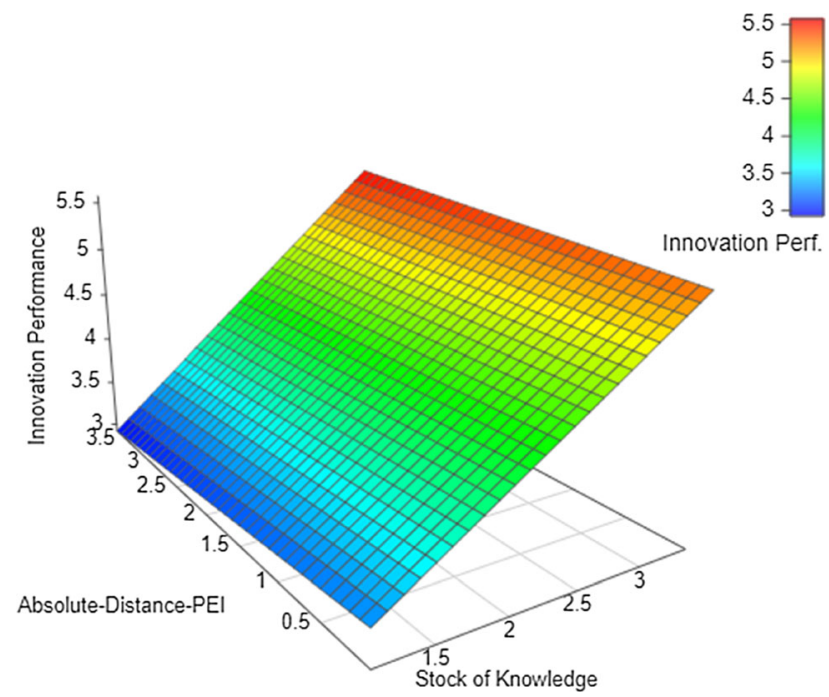

Graph 4b Margins 3-D plot: (Table 6 column 1 if positive distance dummy=0). The three numbers at the vertices of the parallelepiped are respectively: (a) 1 st number, the minimum (1.10) and the maximum (3.90) values of stock of knowledge ( $x$ axis); (b) 2nd number, the minimum (3.70) and the maximum (7.63) values of innovation performance (z-axis); dark blue dots indicate low innovation performance (towards the minimum), green dots indicate signal intermediate levels, while red dots indicate high innovation performance (towards the maximum). (c) 3rd number, the minimum (0.00) and the maximum (4.20) values of absolute distance of firm-patent-enforcement-index ( $y$ axis). case. Indeed, we find the effect of IPR distance on innovation performance actually to be positive when the home location has lower IPR protection, though this effect is not statistically significant at the $95 \%$ level. We suggest that this is a result of different company learning experiences associated with the two cases. Thus, when locating in high IPR protection regimes, emerging economy multinational enterprises (EEMNEs) benefit from richer research environments, absorbing the greater knowledge generated that then feeds into their innovation performance (Zhao, 2006). This factor becomes more marked as IPR distance increases, i.e., as IPR protection increases relative to the home country. In contrast, MNEs based in high IPR protection home countries find it more expensive to protect their knowledge creation process in locations with lower IPR protection. This is consistent with the idea that MNEs from low IPR countries investing in higher IPR countries benefit increasingly from the improving local research environment (e.g., Huawei locating R\&D facilities in Canada), but such compensations are not available for MNEs from high IPR protection countries investing in locations with low IPR protection (e.g., Daimler doing R\&D in China, Cote et al., 2020a, 2020b).

The case of what we term positive Home-Host F-PEI Distance, when IPR protection is stronger in host than the home location, has particular resonance because of the increasing significance of EEMNEs in the global economy (Cuervo-Cazzura \& Genc, 2008; Cuervo-Cazurra \& Ramamurti, 2014). EEMNEs often derive from home countries characterized by institutional environments less prone to IPR enforcement and protection (Peng et al., 2017). As EEMNEs become more prevalent, their strategic decisions have entailed choices about where to locate their own R\&D activities and, as with MNEs from developed economies, they have three choices: at home; abroad in an economy with weak IPR protection; or in an economy where IPR protection is strong. Examples of the latter two include South Korea's Samsung locating R\&D divisions in India or the Chinese electrical giant Haier's innovation units in the US and Europe. Indeed, the option to locate inventive capabilities in developed economies allows some EMMNEs to escape the loss of appropriability within their own low IPR regime country (Cuervo-Cazurra \& Ramamurti, 2017). Our results suggest that, while locating $R \& D$ facilities overseas to locations with different levels of IPR protection may weaken innovation performance 
for MNEs from advanced economies, these distance effects may be less marked, or indeed not exist, for EEMNEs. This may help to explain the recent growth in EEMNE investment in advanced economies; innovation performance may not be greatly affected by distance for MNEs whose home base is characterized by low IPR protection.

\section{CONCLUSIONS}

Our attention in this paper has been on the innovation performance of highly innovative MNEs. We use a knowledge production methodology to explain how innovation performance is affected by the geographic distribution of the firm's research capabilities and the levels of IPR protection afforded in these different locations. In this way, we have enriched our understanding of how MNEs use their inventive capabilities to produce the patents which represent a key element of the ownership advantages underlying their internationalization (Cantwell, 1989; Narula, 2014). Our work also deepens our understanding of the way that institutional contexts influence the strategic decisions of highly inventive MNEs. The IB literature has extensively analyzed how institutional context influences key strategic MNE decisions such as entry mode, location choice, and homecountry effects (Meyer \& Peng, 2016). While considerable work has been undertaken concerning R\&D offshoring (Rosenbusch et al., 2019) and the impact of IPR protection (Belderbos et al., 2013; Cantwell, Dunning, \& Lundan, 2010), we specifically focus on how such contextual factors moderate the knowledge production process within the firm. We propose that, even though the internationalization of R\&D may yield benefits to the firm (Castellani et al., 2013), transactions and coordination costs will be higher in overseas than domestic research units (Criscuolo \& Narula, 2007). Moreover, this negative effect on innovation performance will rise as the difference in IPR protection between home and host economy increases. However, this effect is asymmetric; it will be more pronounced for MNEs from high IPR locations which base R\&D units in countries with lower IPR protection. Our database on the MNEs which undertake the bulk of global patenting supports all these hypotheses.

This paper explores the determinants of innovation performance in terms of the geographic location of MNE activities and the institutional characteristics of those locations. This has been made feasible by the development of our dataset, which allows consideration of inventive capabilities and innovation output for all highly innovative MNEs, as well as an analysis of R\&D locations and country-level institutional factors including the strength of IPR protection. However, the dataset is also subject to some important limitations. It does not contain information that would allow us to analyze the choice of location of $R \& D$ facilities overseas (Lahiri, 2010). Hence, in our analysis, we take the geographic distribution of inventors as given and explore the effects of this internal geography on innovation performance. Future work with access to information to data about the factors motivating location choice might attempt to study the selection and effects of MNE internal geography simultaneously.

Related to this, our empirical analysis is restricted to factors internal to the firm. The literature on innovation has also stressed the public good characteristics of the innovation process, and especially the locational factors within regional and national innovation ecosystems (Audretsch \& Feldman, 2004; Charlot, Crescenzi, \& Musolesi, 2015). In future work, it will be important to bring together the internal and the external factors underlying knowledge production, and the relationship between them (Santangelo et al., 2016) for a more rounded evaluation of the knowledge production process. Moreover, our measure of innovation performance is patenting, a measure of innovation with well-known limitations (e.g., Archibugi, 1992; Pavitt, 1985) in particular with reference to its sensitivity to IPR regimes. With reference to this, it would be interesting to extent our initial results by exploring the use of different dependent variables, such as productivity, which are less influenced by IPR conditions. Finally, our dataset considers only highly innovative MNEs, and in future work, researchers may consider whether the knowledge production process is different in MNEs and homebased firms; and whether highly innovative MNEs, the firms responsible for the bulk of patents globally, generate innovations and react to institutional contexts differently to firms that innovate less frequently.

Our findings have also managerial implications. Our estimates of the knowledge production function indicate that within our sample of highly innovative firms, innovation performance is not greatly influenced by firm size. This suggests that relatively smaller firms can perform as well as large ones in the innovation space. Our finding about 
the negative impact of weak IPR protection, and the negative effects of distance, also make salutary reading for managers contemplating offshoring $\mathrm{R} \& \mathrm{D}$, especially for MNEs based in high IPR protection locations. There are many benefits from locating innovation abroad in terms of accessing skills, plugging into research hubs and understanding new markets (Athreye, Batsakis, \& Singh, 2016; Berry, 2014;). However, our work supports the view of Belderbos et al. (2013) that there are also costs, and that these increase with the distance in the strength of IPR protection between the home and host economies.

Our study opens up several lines of enquiry for future work. Perhaps the most important would be to consider in more depth the impact of contextual factors on the firm-level knowledge production process and the implications for MNE strategy. Our work suggests that the strictness of IPR protection affects strategic outcomes, but the next stage of research might be to integrate the analysis of knowledge production, R\&D offshoring and IPR protection to analyze the implications for MNE innovation performance. Furthermore, recent IB literature has focused extensively on emerging market MNEs suggesting that there are fundamental differences from developed economy MNEs in terms of their ownership advantages (CuervoCazurra and Ramamurti 2014, 2017) arising in part from their home-country institutional arrangements (e.g., Estrin, Meyer, \& Pelletier, 2018). One of the important differences that has been identified is that EMMNEs do not necessarily have ownership advantages that stem from technological superiority, itself driven by their patents and innovation processes (Luo \& Tung, 2007). This suggests that a specific comparison of the knowledge production technology between developed and emerging economies could be a fruitful line of enquiry for new research.

\section{ACKNOWLEDGEMENTS}

This research has received funding from the European Research Council under the European Union Horizon 2020 Programme H2020/2014-2020 (Grant Agreement n 639633-MASSIVE-ERC-2014-STG) and European Union Horizon 2020 Research and Innovation action (Grant Agreement n 822781-GROWINPRO).
This paper is part of the output of the cooperation between the authors and Sara Amoroso for IRI team (B3 JRC-Seville, see Hernández, H., Grassano, N., Tübke, A., Amoroso, S., Csefalvay, Z., and Gkotsis, P.: The 2019 EU Industrial R\&D Investment Scoreboard; EUR 30002 EN; Publications Office of the EU, Luxembourg, 2020) in the framework of the ERC MASSIVE Project. We are grateful to Sara Amoroso and the IRI team for their cooperation and support with Scoreboard data and for their comment on an earlier draft of the paper. We also gratefully acknowledge the provision of IPR data by Nick Papageorgiadis, as well as valuable comments from Rajneesh Narula, Klaus Meyer, and three anonymous referees. We thank Thamashi De Silva for excellent research assistance. All errors are the authors' alone.

\section{NOTES}

${ }^{1}$ This information is compiled and organized in Patents/View, which is a patent data visualization and analysis platform supported by the Office of the Chief Economist in the USPTO.

${ }^{2}$ Compiled by the Bureau van Dijk Electronic Publishing, BvD.

${ }^{3}$ Five-year averaging smooths the annual patents' data, which are highly volatile.

${ }^{4}$ This index shows substantial cross-country variability as well as time series dynamics within each country. See also Papageorgiadis et al. (2020a).

${ }^{5}$ In other words, the Home-Host Relative IPR protection combines country level institutional settings and firms' level geographical distribution of patents through time.

${ }^{6}$ All employees, not only those who are R\&Drelated.

${ }^{7}$ We also use country-time trends for robustness.

${ }^{8}$ Papageorgiadis and Sofka (2020) have updated the PEI popularized by Papageorgiadis et al. (2014). We have built a firm-level IPR indicator. The distribution of such indicator is shown in Figure 1: the first quartile is located at 6.95 and the third at 8.4. For this reason, the thresholds have been selected around these quartiles. 
${ }^{9}$ The Wald test of equality of the two coefficients with the null hypothesis being $\alpha_{3}=\alpha_{2}$ is rejected with $p$ value 0.000 .

${ }^{10}$ In columns 3 and 4 , we run a robustness check using as sample split of countries with high home PEI vs. countries with low home PEI and the results are fully consistent.

\section{REFERENCES}

Alcácer, J., \& Chung, W. 2007. Location strategies and knowledge spillovers. Management Science, 53(5): 760-776.

Anand, J., McDermott, G., Mudambi, R., \& Narula, R. 2021. (Forthcoming). Innovation in and from emerging economies: New insights and lessons for international business research. Journal of International Business Studies.

Archibugi, D. 1992. Patenting as an indicator of technological innovation: a review. Science and Public Policy, 19(6): 357-368.

Arora, A., Cohen, W. M., \& Cunningham, C. M. 2018. Inventive capabilities in the division of innovative labor. NBER Working Paper Series, no. w25051. Cambridge, MA: National Bureau of Economic Research.

Athreye, S., Batsakis, G., \& Singh, S. 2016. Local, global, and internal knowledge sourcing: The trilemma of foreign-based R\&D subsidiaries. Journal of Business Research, 69(12): 5694-5702.

Audretsch, D., \& Feldman, M. 2004. Knowledge Spillovers and the geography of innovation. Handbook of Urban and Regional Economics, 4: 2713-2739.

Baldwin, C. Y., \& Henkel, J. 2015. Modularity and intellectual property protection. Strategic Management Journal, 36: 1637-1655.

Belderbos, R., Leten, B., \& Suzuki, S. 2013. How global is R\&D? Firm-level determinants of home-country bias in R\&D. Journal of International Business Studies, 44: 765-786.

Berry, H. 2014. Global integration and innovation: multicountry knowledge generation within MNC s. Strategic Management Journal, 35(6): 869-890.

Berry, H., Guillén, M. F., \& Zhou, N. 2010. An institutional approach to cross-national distance. Journal of International Business Studies, 41(9): 1460-1480.

Bevan, A. A., \& Estrin, S. 2004. The determinants of foreign direct investment into European transition economies. Journal of Comparative Economics, 32(4): 775-787.

Beugelsdijk, S., Ambos, B. \& Nell, P. C. 2020. Conceptualizing and Measuring Distance in International Business Research: Recurring Questions and Best Practice Guidelines. In L. Eden, B.B. Nielsen \& A. Verbeke (Eds.): Research Methods in International Business: 449-498. Cham: Palgrave Macmillan.

Birkinshaw, J. M., \& Hood, N. 1998. Multinational subsidiary evolution: Capability and charter change in foreign-owned subsidiary companies. Academy of Management Review, 23(4): 773-795.

Blanc, H., \& Sierra, C. 1999. The internationalisation of R\&D by multinationals: A trade-off between external and internal proximity. Cambridge Journal of Economics, 23(2): 187-206.

Blanc-Brude, F., Cookson, G., Piesse, J., \& Strange, R. 2014. The FDI location decision: Distance and the effects of spatial dependence. International Business Review, 23(4): 797-810.

Brander, J. A., Cui, V., \& Vertinsky, I. 2017. China and intellectual property rights: A challenge to the rule of law. Journal of International Business Studies, 44: 765-786.

Cano-Kollmann, M., Cantwell, I., Hannigan, T. J., Mudambi, R., \& Song, J. 2016. Knowledge connectivity: An agenda for innovation research in international business. Journal of International Business Studies, 47: 255-262.
${ }^{11}$ The Wald test of equality of the two coefficients is rejected at the $1 \%$ level with $p$ value 0.000 .

${ }^{12}$ The Wald test of equality of the two coefficients is rejected at the $1 \%$ level with $p$ value 0.000 .

Cantwell, J. A. 1989. Technological innovation and multinational corporations. Basil Blackwell.

Cantwell, J. A., Dunning, J. H., \& Lundan, S. M. 2010. An evolutionary approach to understanding international business activity: The co-evolution of MNEs and the institutional environment. Journal of International Business Studies, 41(4): 567-586.

Cassiman, B., \& Veugelers, R. 2002. R\&D cooperation and spillovers: some empirical evidence from Belgium. American Economic Review, 92(4): 1169-1184.

Casson, M. 1985. Transaction Costs and the Theory of the Multinational Enterprise. In: P. Buckley, \& M. Casson (Ed), The Economic Theory of the Multinational Enterprise. London, UK: Palgrave Macmillan.

Castellani, D., Jimenez, A., \& Zanfei, A. 2013. How remote are R\&D labs? Distance factors and international innovative activities. Journal of International Business Studies, 44: 649-675.

Cavusgil, T., Calantone, R., \& Zhao, Y. 2003. Tacit knowledge transfer and firm innovation capability. Journal of Business \& Industrial Marketing, 18: 6-21.

Charlot, S., Crescenzi, R., \& Musolesi, A. 2015. Econometric modelling of the regional knowledge production function in Europe. Journal of Economic Geography, 15: 1227-1259.

Christensen, C. 2006. The ongoing process of building a theory of disruption. Journal of Product Innovation Management, 23: $39-55$.

Cote, C., Estrin, S., Nunner, K., \& Shapiro, D. 2020. Daimler: Motoring at the speed of China. Ivey Case no: 9B20M023.

Cote, C., Estrin, S., \& Shapiro, D. 2020b. Expanding the international trade and investment policy agenda: The role of cities and services. Journal of International Business Policy, 3(3): 199-223.

Crescenzi, R., Nathan, M., \& Rodríguez-Pose, A. 2016. Do inventors talk to strangers? On proximity and collaborative knowledge creation. Research Policy, 45(1): 177-194.

Crescenzi, R., \& Gagliardi, L. 2018. The innovative performance of firms in heterogeneous environments: The interplay between external knowledge and internal absorptive capacities. Research Policy, 47(4): 782-795.

Criscuolo, P., Narula, R., \& Verspagen, B. 2005. Role of home and host country innovation systems in R\&D internationalisation: a patent citation analysis. Economics of Innovation and New Technology, 14(5): 417-433.

Criscuolo, P., \& Narula, R. 2007. Using multi-hub structures for international R\&D: Organisational inertia and the challenges of implementation. Management International Review, 47: 639-660.

Crossan, M. M., \& Apaydin, M. 2010. A multi-dimensional framework of organizational innovation: A systematic review of the literature. Journal of Management Studies, 47(6): 1154-1191.

Cuervo-Cazurra, A., \& Genc, M. 2008. Transforming disadvantages into advantages: Developing-country MNEs in the least developed countries. Journal of International Business Studies, 39(6): 957-979. 
Cuervo-Cazurra, A., \& Ramamurti, R. 2014. Understanding multinationals from emerging markets. Cambridge University Press.

Cuervo-Cazurra, A., \& Ramamurti, R. 2017. Home country underdevelopment and internationalization: Innovation-based and escape-based internationalization. Competitiveness Review, 27(3): 217-230.

Dachs, B., Stehrer, R., \& Zahradnik, G. (Eds.). 2014. The internationalisation of business $R \& D$. Edward Elgar.

De Propris, L. \& Driffield, N. 2006. FDI, clusters and knowledge sourcing. In C. Pitelis, R. Sugden, \& J. Wilson (Eds.), Clusters and globalisation: the development of urban and regional economies: 133-158. Cheltenham, UK: Edward Elgar.

Doh, J. P., Bunyaratavej, K., \& Hahn, E. D. 2009. Separable but not equal: the location determinants of discrete services offshoring activities. Journal of International Business Studies, 40: 926-943.

Dunning, J. H. 1988. The eclectic paradigm of international production: A restatement and some possible extensions. Journal of International Business Studies, 19(1): 1-31.

Eisenhardt, K. M., \& Martin, J. A. 2000. Dynamic capabilities: what are they? Strategic Management Journal, 21: 1105-1121.

Estrin, S., Meyer, K. E., \& Pelletier, A. 2018. Emerging economy MNEs: how does home country munificence matter? Journal of World Business, 53(4): 514-528.

Ghemawat, P. 2007. Redefining global strategy: Crossing borders in a world where differences still matter. Harvard Business Press.

Global EV Report. 2020. https://www.iea.org/reports/global-evoutlook-2020.

Globerman, S., \& Shapiro, D. 2002. Global foreign direct investment flows: The role of governance infrastructure. World Development, 30(11): 1899-1919.

Griliches, Z. 1979. Issues in assessing the contribution of R\&D to productivity growth. The Bell Journal of Economics, 10: 92-116.

Hayton, J., \& Zahra, S. 2005. Venture team human capital and absorptive capacity in high technology new ventures. International Journal of Technology Management, 31(3-4): 256-274.

Hollanders, H., Es-Sadki, N., Vértesy, D., \& Damioli, G. 2017. European innovation scoreboard 2017-methodology report. European Commission.

Jackson, G., \& Deeg, R. 2008. Comparing capitalisms: understanding institutional diversity and its implications for international business. Journal of International Business Studies, 39: 540-561.

Kshetri, N. 2007. Institutional factors affecting offshore business process and information technology outsourcing. Journal of International Management, 13: 38-56.

Khoury, T. A., \& Peng, M. W. 2011. Does institutional reform of intellectual property rights lead to more inbound FDI? Evidence from Latin America and the Caribbean. Journal of World Business, 46(3): 337-345.

Kogut, B., \& Zander, U. 1993. Knowledge of the firm and the evolutionary theory of the multinational corporation. Journal of International Business Studies, 24(4): 625-645.

Kostova, T., Beugelsdijk, S., Scott, W. R., Kunst, V., Chua, C. H., \& van Essen, M. 2020. The construct of institutional distance through the lens of different institutional perspectives: Review, analysis, and recommendations. Journal of International Business Studies, 51: 467-497.

Kotabe, M., Dunlap-Hinkler, D., Parente, R., \& Mishra, H. A. 2007. Determinants of cross-national knowledge transfer and its effect on firm innovation. Journal of International Business Studies, 38: 259-282.

Lahiri, N. 2010. Geographic distribution of R\&D activity: how does it affect innovation quality? Academy of Management Journal, 53: 1194-1209.

Lazzarini, S. G., Mesquita, L. F., Monteiro, F., \& Musacchio, A. 2021. (Forthcoming). Leviathan as an inventor: An extended agency model of state-owned versus private firm invention in emerging and developed economies. Journal of International Business Studies.

Lee, J. M., Narula, R., \& Hillemann, J. 2021. Unraveling asset recombination through the lens of firm-specific advantages: a dynamic capabilities perspective. Journal of World Business, 56(2): 101193.

Leiponen, A., \& Helfat, C. E. 2010. Innovation objectives, knowledge sources, and the benefits of breadth. Strategic Management Journal, 31(2): 224-236.

Lewin, A. Y., Massini, S., \& Peeters, C. 2009. Why are companies offshoring innovation? The emerging global race for talent. Journal of International Business Studies, 40: 901-925.

Li, X., \& Zhou, Y. M. 2017. Offshoring pollution while offshoring production? Strategic Management Journal, 38: 2310-2329.

Luo, Y., \& Tung, R. L. 2007. International expansion of emerging market enterprises: A springboard perspective. Journal of International Business Studies, 38(4): 481-498.

Marano, V., Arregle, J. L., Hitt, M. A., Spadafora, E., \& van Essen, M. 2016. Home country institutions and the internationalization-performance relationship. Journal of Management, 42(5): 1075-1110.

Marvel, M. R., \& Lumpkin, G. T. 2007. Technology entrepreneurs' human capital and its effects on innovation radicalness. Entrepreneurship Theory and Practice, 31(6): 807-828.

Meyer, K. E., \& Peng, M. W. 2016. Theoretical foundations of emerging economy research. Journal of International Business Studies, 47(1): 3-22.

Minbaeva, D. B., Pedersen, T., Björkman, I., \& Fey, C. F. 2014. A retrospective on: MNC knowledge transfer, subsidiary absorptive capacity, and HRM. Journal of International Business Studies, 45(1): 52-62.

Mudambi, R. 2008. Location, control and innovation in knowledge-intensive industries. Journal of Economic Geography, 8(5): 699-725.

Nandkumar, A., \& Srikanth, K. 2016. Right person in the right place: How the host country IPR influences the distribution of inventors in offshore R\&D projects of multinational enterprises. Strategic Management Journal, 37(8): 1715-1733.

Narula, R. 2003. Globalization and technology: Interdependence, innovation systems and industrial policy. Polity Press.

Narula, R. 2014. Exploring the paradox of competence-creating subsidiaries: balancing bandwidth and dispersion in MNEs. Long Range Planning, 47(1-2): 4-15.

Nelson, R. R., \& Winter, S. G. 1982. An evolutionary theory of economic change. The Belknap Press of Harvard University Press.

Papanastassiou, M., Pearce, R., \& Zanfei, A. 2020. Changing perspectives on the internationalization of $R \& D$ and innovation by multinational enterprises: A review of the literature. Journal of International Business Studies, 51(4): 623-664.

Papageorgiadis, N., McDonald, F., Wang, C., \& Konara, P. 2020. The characteristics of intellectual property rights regimes: How formal and informal institutions affect outward FDI location. International Business Review, 29(1).

Papageorgiadis, N., Cross, A. R., \& Alexiou, C. 2014. International patent systems strength 1998-2011. Journal of World Business, 49(4): 586-597.

Papageorgiadis, N., \& Sofka, W. 2020. Patent enforcement across 51 countries-patent enforcement index 1998-2017. Journal of World Business, 55(4): 101092.

Park, W. G. 2008. International patent protection: 1960-2005. Research Policy, 37(4): 761-766.

Pavitt, K. 1985. Patent statistics as indicators of innovative activities: Possibilities and problems. Scientometrics, 7: 77-99.

Peng, M. W., Ahlstrom, D., Carraher, S. M., \& Shi, W. 2017. An institution-based view of global IPR history. Journal of International Business Studies, 48(1): 893-907.

Phene, A., \& Almeida, P. 2008. Innovation in multinational subsidiaries: The role of knowledge assimilation and subsidiary capabilities. Journal of International Business Studies, 39(5): 901-919. 
Pisano, G. P., \& Teece, D. J. 2007. How to capture value from innovation: Shaping intellectual property and industry architecture. California Management Review, 50(1): 278-296.

Rosenbusch, N., Gusenbauer, M., Hatak, I., Fink, M., \& Meyer, K. E. 2019. Innovation offshoring, institutional context and innovation performance: A meta-analysis. Journal of Management Studies, 56(1): 203-233.

Rugman, A. M. (Ed.). 2009. The Oxford handbook of international business. Oxford University Press.

Rugman, A., \& Verbeke, A. 2001. Subsidiary-specific advantages in multinational enterprises. Strategic Management Journal, 22(3): 237-251.

Santangelo, G. D., Meyer, K. E., \& Jindra, B. 2016. MNE subsidiaries' outsourcing and insourcing of R\&D: The role of local institutions. Global Strategy Journal, 6(4): 247-268.

Shenkar, O. 2001. Cultural distance revisited: Towards a more rigorous conceptualization and measurement of cultural differences. Journal of International Business Studies, 32(3): 519-535.

Shrader, R., \& Siegel, D. 2007. Assessing the relationship between human capital and firm performance evidence from technology-based new ventures. Entrepreneurship Theory and Practice, 31(6): 893-908.

Teece, D. J. 2007. Explicating dynamic capabilities: the nature and microfoundations of (sustainable) enterprise performance. Strategic Management Journal, 28(13): 1319-1350.

Teece, D. J. 2014. A dynamic capabilities-based entrepreneurial theory of the multi-national enterprise. Journal of International Business Studies, 45(1): 8-37.

Zaheer, S., Schomaker, M., \& Nachum, L. 2012. Distance without direction: Restoring credibility to a much-loved construct. Journal of International Business Studies, 43(1): $18-27$.

Zhao, M. 2006. Conducting R\&D in countries with weak intellectual property rights protection. Management Science, 52(8): 1185-1199.

\section{APPENDIX}

Correlations, VIF, and additional analysis of Hypothesis 3. In Table 4, we present the correlation between all independent variables and in Table 5 the VIF factors. They give little cause for concern about multicollinearity in our sample.

In order to further explore Hypothesis 3, we specify a triple interaction model where the impact of inventive capability is moderated by absolute value of the |Home-Host F-PEI Distance| and by the direction of the distance. This will be positive when the IPR regime in the home country is stricter than the F-PEI: it is negative if the converse is true. We call this dummy variable the Home-Host F-PEI Direction DUMMY. This new specification is introduced in Eq. (7):

$$
\begin{aligned}
& \log \left(\mathrm{y}_{\text {itc }}\right)=\alpha_{0}+\eta_{1} \log (\text { INVENTIVE CAPABILITIES })_{\text {itc }} \\
& +\eta_{2}\left[\log (\text { INVENTIVE CAPABILITIES })_{\text {itc }}\right. \\
& * \mid \text { Home - Host F-PEI distance } e_{\text {itc }} \mid \\
& +\eta_{3}\left[\log (\text { INVENTIVE CAPABILITIES })_{\text {itc }}\right. \\
& \text { *(Home - Host F-PEI Direction DUMMY } \left.)_{\mathrm{itc}}\right] \\
& +\eta_{4}\left[\log (\text { INVENTIVE CAPABILITIES })_{\text {itc }}\right. \\
& * \mid \text { Home - Host F - PEI distance itc } \mid] \\
& \text { *(Home - HostF - PEI Direction DUMMY } \left.)_{\mathrm{itc}}\right] \\
& +\eta_{5} \mid \text { Home }- \text { Host } F-\text { PEI distance } i t c \mid \\
& +\eta_{6} \mid \text { Home }- \text { Host } F-\text { PEI distance } i t c \mid \\
& \text { *(Home }- \text { Host F - PEI Direction DUMMY })_{\text {itc }} \\
& +\eta_{7} *(\text { Home }- \text { Host F-PEI Direction DUMMY })_{\mathrm{itc}} \\
& +\eta_{8}(\text { FIRM CONTROLS })_{\text {itc }}+t_{\mathrm{t}}+\mu_{\mathrm{i}+} \varepsilon_{\mathrm{itc}}
\end{aligned}
$$

On this basis, we can explore Hypothesis 3 in greater depth, using graphs to show the combined marginal effects. We expect that the 3-D graph of the predicted patenting margins for different combinations of inventive capabilities and F-PEI distance would show that inventive capabilities are more conducive to patenting in MNEs from lower IPR protection countries that offshore $R \& D$ into higher IPR protection countries than for MNEs from higher IPR countries investing in lower IPR economies. Table 6 shows the estimates of the triple interaction model (including the term inventive capabilities*|Home-Host F-PEI distance ${ }^{*}$ Direction). In column (1) of Table 6 we show the estimates using the distance measure, as in columns (1) and (2) in Table 3; in column (2) we instead use the home level PEI as in columns (3) and (4) of Table 3. 


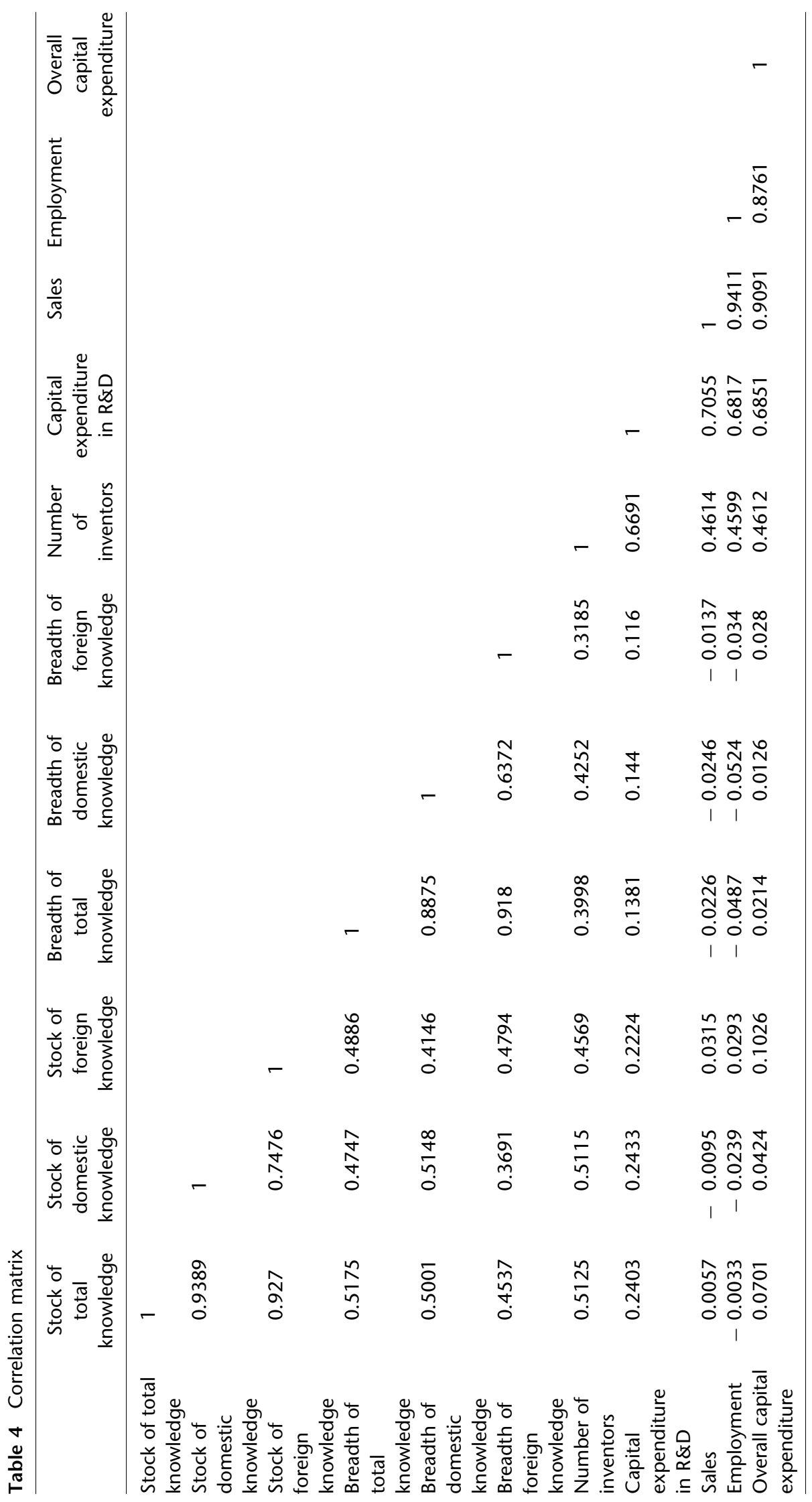


Table 5 Variance inflation factors

\begin{tabular}{lcc}
\hline Variable & VIF & $1 /$ VIF \\
\hline Stock of knowledge & 1.79 & 0.5579 \\
Breadth of knowledge & 1.51 & 0.66443 \\
Number of inventors & 2.63 & 0.38021 \\
Capital expenditure in R\&D & 2.9 & 0.34493 \\
Sales & 12.51 & 0.07993 \\
Employment & 9.25 \\
Overall capital expenditure & 6.13 & 0.10808 \\
Time dummies & & 0.16301 \\
2005 & 2.05 \\
2006 & 2.13 \\
2007 & 2.17 & 0.48676 \\
2008 & 2.21 & 0.46992 \\
2009 & 2.22 & 0.4599 \\
2010 & 2.21 & 0.45342 \\
2011 & 2.25 & 0.45074 \\
2012 & 2.32 & 0.4519 \\
2013 & 2.36 & 0.44505 \\
Mean VIF & 3.54 & 0.43074 \\
\hline
\end{tabular}

Author's computation based on baseline regression without interactions and fixed effects.

Table 6 The role of absolute distance and its direction (via fully interacted model)

\begin{tabular}{|c|c|c|}
\hline Dep: patents per firm & $(1)$ & $(2)$ \\
\hline & Direction & Home PEI level \\
\hline \multirow[t]{3}{*}{ Stock knowledge } & 1.402 & 1.316 \\
\hline & $(0.093)$ & $(0.086)$ \\
\hline & {$[0.000]$} & {$[0.000]$} \\
\hline \multirow[t]{3}{*}{ Stock knowledge \# |Home-Host F-PEI distance $\mid$} & -0.054 & -0.136 \\
\hline & $(0.100)$ & $(0.053)$ \\
\hline & [0.587] & {$[0.011]$} \\
\hline \multirow[t]{3}{*}{ Stock knowledge \#|Home-Host F-PEI distance|\#(positive distance dummy(or)high PEI) } & -0.091 & -0.009 \\
\hline & $(0.103)$ & $(0.035)$ \\
\hline & {$[0.377]$} & {$[0.787]$} \\
\hline \multirow[t]{3}{*}{ Stock knowledge \#(positive distance dummy(or)High PEI) } & -0.039 & 0.067 \\
\hline & $(0.047)$ & $(0.034)$ \\
\hline & {$[0.403]$} & {$[0.047]$} \\
\hline \multirow[t]{3}{*}{ |Home-Host F-PEI distance| } & 0.119 & 0.236 \\
\hline & $(0.168)$ & $(0.089)$ \\
\hline & {$[0.480]$} & {$[0.008]$} \\
\hline \multirow[t]{3}{*}{ Positive distance(or)high PEI } & 0.048 & -0.491 \\
\hline & $(0.082)$ & $(0.213)$ \\
\hline & {$[0.555]$} & {$[0.022]$} \\
\hline \multirow[t]{3}{*}{ Positive distance dummy(or)high PEI \# |Home-Host F-PEI distance| } & 0.151 & 0.036 \\
\hline & $(0.173)$ & $(0.065)$ \\
\hline & [0.383] & {$[0.575]$} \\
\hline \multirow[t]{3}{*}{ Inventors per firm } & 1.063 & 1.064 \\
\hline & $(0.020)$ & $(0.020)$ \\
\hline & {$[0.000]$} & {$[0.000]$} \\
\hline
\end{tabular}


Table 6 (Continued)

\begin{tabular}{|c|c|c|}
\hline Dep: patents per firm & $(1)$ & $(2)$ \\
\hline \multirow[t]{3}{*}{$R \& D$ investment } & -0.630 & -0.634 \\
\hline & $(0.300)$ & $(0.298)$ \\
\hline & {$[0.036]$} & {$[0.033]$} \\
\hline \multirow[t]{3}{*}{$R \& D$ investment \# R\&D investment } & 0.135 & 0.135 \\
\hline & $(0.060)$ & $(0.060)$ \\
\hline & {$[0.025]$} & {$[0.025]$} \\
\hline \multirow[t]{3}{*}{$R \& D$ investment \# R\&D investment \# R\&D investment } & -0.009 & -0.009 \\
\hline & $(0.004)$ & $(0.004)$ \\
\hline & {$[0.020]$} & {$[0.020]$} \\
\hline \multirow[t]{3}{*}{ Sales } & 0.000 & 0.004 \\
\hline & $(0.050)$ & $(0.050)$ \\
\hline & {$[0.993]$} & {$[0.937]$} \\
\hline \multirow[t]{3}{*}{ Employees } & -0.103 & -0.101 \\
\hline & $(0.060)$ & $(0.060)$ \\
\hline & {$[0.083]$} & {$[0.089]$} \\
\hline \multirow[t]{3}{*}{ Capital } & 0.047 & 0.045 \\
\hline & $(0.022)$ & $(0.022)$ \\
\hline & {$[0.035]$} & {$[0.041]$} \\
\hline \multirow[t]{3}{*}{ Constant } & -0.548 & -0.115 \\
\hline & $(0.526)$ & $(0.567)$ \\
\hline & {$[0.298]$} & {$[0.839]$} \\
\hline Observations & 6,023 & 6,023 \\
\hline Number of unique BVD identifiers & 874 & 874 \\
\hline Adjusted R-squared & 0.865 & 0.865 \\
\hline Firm FE & YES & YES \\
\hline Year FE & YES & YES \\
\hline Country-year FE & YES & YES \\
\hline
\end{tabular}

For the full specification of the model, see Eq. 5 in the text. Robust standard errors are in "( $)$ " parentheses and $p$ values are in "[ ]" brackets.

\section{ABOUT THE AUTHORS}

Randolph Luca Bruno is Associate Professor of Economics at University College London, SSEES. He is research fellow at IZA-Bonn and senior research fellow Fondazione Rodolfo DeBenedetti-Milan. His main research interests revolve around international business and comparative economics with a focus on the role of institutions and technology.

Riccardo Crescenzi is a Professor of Economic Geography at the London School of Economics and is the current holder of a European Research Council (ERC) grant. He is also a Research Associate at the Centre for International Development at the Harvard Kennedy School of Government. His research is focused on regional economic development and growth, innovation, multinational firms and the analysis and evaluation of public policies.

Saul Estrin is a Professor of Managerial Economics and Strategy and was the founding Head of the Department of Management at LSE. He was formerly a Professor of Economics at London Business
School. His research covers a range of subjects in international business, especially with reference to emerging and transition economies.

Sergio Petralia is an Assistant Professor in Economic Geography at Utrecht University and a Postdoctoral Researcher part of the ERC MASSIVE Project at London School of Economics. He works on issues related to technological change and innovation. His most recent projects study the emergence and spatial concentration of complex technologies using historical data on patent activity and the distributional impact of the emergence and diffusion of disruptive technologies.

Open Access This article is licensed under a Creative Commons Attribution 4.0 International License, which permits use, sharing, adaptation, distribution and reproduction in any medium or format, as long as you give appropriate credit to the original author(s) and the source, provide a link to the Creative Commons licence, and indicate if changes were made. The images or other third party 
material in this article are included in the article's Creative Commons licence, unless indicated otherwise in a credit line to the material. If material is not included in the article's Creative Commons licence and your intended use is not permitted by statutory regulation or exceeds the permitted use, you will need to obtain permission directly from the copyright holder. To view a copy of this licence, visit http://creativecommons.org/licenses/by/4.0/.

Publisher's Note Springer Nature remains neutral with regard to jurisdictional claims in published maps and institutional affiliations.

Accepted by Rajneesh Narula, Area Editor, 10 May 2021. This article has been with the authors for four revisions. 